\title{
Continuidades e Descontinuidades da Federação Brasileira: De como 1988 Facilitou 1995*
}

\author{
Marta Arretche
}

[...] não podemos deixar ao bel-prazer das leis complementares estaduais a criação de municípios.

[...] temos a oportunidade de cumprir o mandato constitucional que determina a regulamentação do [principal imposto estadual] através de lei complementar [federal].

A s afirmações acima não são de autoria de nenhum dos pensadores autoritários da década de 1920, tampouco podem ser interpretadas como uma reação centralizadora à excessiva autonomia conferida aos governos estaduais no arranjo federativo vigente. A primeira é de um deputado federal do Partido da Frente Liberal (PFL) baiano. Foi pronunciada na Câmara dos Deputados, em 14 de abril de 1996, por

\footnotetext{
* Versões preliminares deste artigo foram apresentadas como parte de minha tese de livre-docência na Universidade de São Paulo (USP), no 6oㅡㄹ Encontro da Associação Brasileira de Ciência Política (ABCP), bem como em seminário no Centro de Estudos da Metrópole (CEM)/Centro Brasileiro de Análise e Planejamento (Cebrap). Agradeço os comentários de Gilberto Hochman, Telma Menicucci, Argelina Figueiredo, Maria Hermínia Tavares de Almeida, Fernando Limongi, Sônia Draibe, Eli Diniz e Gildo Marçal Brandão. Agradeço a gentileza de Fernando Limongi e Argelina Figueiredo de cederem os dados do Banco Legislativo do Cebrap, bem como a valiosa colaboração de Andréia Freitas no tratamento dos dados estatísticos. Por fim, agradeço o rigor dos pareceristas desta revista, o que muito contribuiu para sua versão final. A versão final deste artigo foi redigida durante minha visiting fellowship, no Instituto Universitário Europeu, com bolsa da Coordenação de Aperfeiçoamento de Pessoal de Nível Superior (Capes).
}

DADOS - Revista de Ciências Sociais, Rio de Janeiro, Vol. 52, n², 2009, pp. 377 a 423. 
ocasião dos debates em torno da aprovação da emenda constitucional (EC) no 15/1996, que restringiu ainda mais o escopo de autoridade exclusiva que a Constituição Federal de 1988 (CF 88) havia conferido aos Estados, devolvendo a autoridade sobre a criação de municípios ao governo federal. A segunda foi pronunciada por um deputado federal do Partido da Social Democracia Brasileira (PSDB) paranaense, em 27 de agosto de 1996, no papel de relator do projeto de lei complementar que deu origem à Lei Kandir, que regulamentou detalhadamente a forma como os governos estaduais arrecadariam o Imposto sobre Circulação de Mercadorias e Serviços (ICMS).

Embora expressivas por seu conteúdo - visto que justificam decisões que suprimiram autoridade decisória dos governos estaduais -, a EC no 15/1996 e a Lei Kandir foram apenas parte de um conjunto de leis federais que impôs expressivas perdas de receita aos Estados e municípios brasileiros, assim como regulou o exercício de suas competências tributárias, de gasto e de implementação de políticas públicas. De fato, não foram de pequena monta as mudanças no status quo federativo brasileiro dos anos 1990. Elas implicaram "expressivo fortalecimento do controle exercido pelo governo federal" (Melo, 2005:845), aproximando o Brasil de "um regime hierárquico, estreitamente administrado, não distinto daquele encontrado em muitos sistemas unitários" (Rodden, 2006:247). A maior parte dos analistas interpretou a aprovação dessa legislação como um processo de recentralização federativa (Abrucio e Costa, 1999; Almeida, 2005; Arretche, 2005; Melo, 2005; Rodden, 2006; Souza, 2002).

Mudanças dessa magnitude requerem explicação, uma vez que esses resultados apontam para a direção oposta àquela esperada por postulados do federalismo comparado, segundo os quais a formação de uma federação supõe um contrato constitucional entre unidades constituintes, que definem proteções institucionais a fim de evitar futuras expropriações por parte das demais unidades ou do governo central. Assim, como foi possível ao governo federal "expropriar" receitas, bem como autoridade sobre impostos, gastos e políticas dos governos subnacionais, sob condições de perfeita normalidade democrática?

Ao longo do século XX, algumas federações - tais como a Austrália e os Estados Unidos - ampliaram a margem de autoridade do governo central sobre os governos subnacionais (Castles e Uhr, 2005; Chibber e Kollman, 2004; Obinger, Leibfried e Castles, 2005; Pierson, 2007). Ou- 
tras - tais como a Áustria, a Índia e a Alemanha - já nasceram centralizadas (Chibber e Kollman, 2004; Manow, 2005; Obinger, Leibfried e Castles, 2005). Nesses casos, a centralização é explicada por contextos excepcionais - tais como guerra ou ameaça de guerra, recessão econômica, construção do Estado nacional ou desenvolvimento do Estado de Bem-Estar (Chibber e Kollman, 2004:227; Obinger, Leibfried e Castles, 2005) -, que criaram condições propícias para que as elites centralizadoras reduzissem as proteções institucionais das unidades constituintes.

Embora, no caso brasileiro, a crise fiscal tenha permitido às elites do governo central justificar medidas de regulação federal como uma urgente necessidade, desempenhando assim um papel análogo ao da "guerra", essa explicação dificilmente pode ser apresentada como convincente para o conjunto das medidas aprovadas, tal como destacou Melo (2005). Diferentes explicações já foram apresentadas para as mudanças no status quo federativo dos anos 1990. Almeida (2005) explorou o papel das ideias argumentando que as elites políticas brasileiras, mesmo quando favoráveis à descentralização, partilham de princípios normativos centralizadores. Abrucio e Costa (1999) atribuíram essas mudanças aos impactos fiscais do Plano Real sobre as preferências dos governadores, as quais teriam causado um comportamento cooperativo das bancadas estaduais em relação às iniciativas legislativas do presidente Fernando Henrique Cardoso. Cheibub, Figueiredo e Limongi $(2006 ; 2009)$ demonstraram que a aprovação dessas medidas pode ser atribuída ao papel dos partidos no comando das votações parlamentares, bem como à baixa coesão das bancadas estaduais e à limitada influência dos governadores sobre seu comportamento.

Curiosamente, a despeito da centralidade do federalismo na agenda de pesquisa sobre as instituições políticas brasileiras, o impacto das regras que regem as interações entre os entes federativos - um tema central do federalismo comparado - não foi suficientemente explorado pela literatura, visto que a maior parte das análises sobre o processo decisório se concentra nas relações entre os poderes, assumindo que o presidente e a União podem ser tomados como análogos ${ }^{1}$, o que significaria assumir que "relações entre poderes" seriam analiticamente equivalentes a "relações entre União e Estados". No caso brasileiro, as instituições que regem as interações entre as unidades constituintes permitem que o jogo legislativo "comece e termine" no Congresso. Requer explicação, entretanto, que o jogo se estabeleça nesses termos em 
vista do postulado de que é próprio das federações criar uma multiplicidade de pontos de veto no processo decisório. Apenas tipos particulares de federações, que centralizam o processo decisório da legislação que afeta os interesses das unidades constituintes, permitem que os principais atores sejam o Executivo federal e o Congresso.

Neste artigo, é examinado o impacto das instituições federativas sobre a possibilidade de o governo federal legislar sobre as políticas dos governos subnacionais com base em duas teorias do federalismo comparado: a das jurisdições e a do poder de veto. Para tanto, é examinado em que medida as instituições federativas brasileiras, instaladas pela CF 88, enable ou constrain o centro (Stepan, 1999). Em outras palavras, se a ampliação da regulação federal nos anos 1990 foi realizada nos marcos das instituições políticas ${ }^{2}$ que regem as interações entre as elites do governo central e dos governos subnacionais, estabelecidas pela Constituição de 1988, é possível avaliar sua influência sobre o processo decisório de matérias de estrito interesse federativo.

O argumento central deste trabalho é que os formuladores da CF 88 criaram um modelo de Estado federativo que combina ampla autoridade jurisdicional à União com limitadas oportunidades institucionais de veto aos governos subnacionais. Não criaram um ambiente institucional que congelasse a distribuição original de autoridade de 1988, pois não estabeleceram regras que exigiriam, no futuro, a mobilização de supermaiorias para alterar aquele contrato original. Além disso, as regras que regem as interações entre as elites do governo federal e dos governos subnacionais favorecem as elites políticas instaladas no centro e limitam as oportunidades de veto das elites instaladas nos governos subnacionais. São essas condições institucionais que permitiram a expansão da autoridade da União sobre os governos subnacionais, além da preponderância do Executivo sobre o Legislativo. Assim, há mais continuidade entre as mudanças aprovadas nos anos 1990 e o contrato original de 1988 do que a noção de uma ruptura entre os dois períodos autorizaria supor.

O artigo está dividido em cinco seções, além desta introdução e das conclusões. A primeira apresenta hipóteses de trajetórias possíveis para a centralização ocorrida nos anos 1990 com base em duas teorias do federalismo comparado: a das jurisdições e a do poder de veto, como já mencionado. A segunda seção apresenta os procedimentos da análise. A terceira está dedicada à análise das mudanças na legislação 
federal que afetaram interesses dos governos subnacionais, com base na distinção conceitual entre execução de políticas e autoridade decisória sobre essas mesmas políticas. A quarta seção explora os determinantes propriamente federativos dessas mudanças. Testa empiricamente se elas podem ser atribuídas a (i) mudanças na agenda da presidência ou a (ii) mudanças no comportamento dos atores com (provável) interesse e capacidade de veto, ambas controladas por mandato presidencial. Essa seção conclui que, em 1995, ocorreu uma mudança na agenda do governo federal, ao passo que o comportamento das bancadas estaduais é constante para todos os mandatos presidenciais. A quinta seção explora o impacto das instituições federativas sobre esse processo decisório.

\section{CENTRO FRACO OU FORTE?}

A análise comparada apresenta dois argumentos para interpretar os mecanismos pelos quais Estados federativos podem afetar mudanças no status quo: a tese da autoridade sobre jurisdições e a tese dos pontos de veto.

A primeira estabelece que a distribuição de autoridade legislativa pode operar como um limitador das iniciativas do governo federal na medida em que a Constituição não confira autoridade a este último para iniciar legislação sobre uma dada área de política (Buchanan, 1995; Inman e Rubinfeld, 1997; Leibfried e Pierson, 1995; Leibfried, Castles e Obinger, 2005; Obinger et alii, 2005; Weingast, 1995). Nesse caso, portanto, um governo central limitado seria aquele em que a União estivesse constitucionalmente proibida de apresentar propostas em políticas específicas. $\mathrm{O}$ argumento que sugere que um extensivo "poder residual dos estados" é indicador de um governo central fraco está relacionado a essa tese (Stepan, 1999). Logo, o efeito do federalismo sobre a capacidade de iniciativa do governo federal dependeria criticamente das áreas de política em que este pode iniciar legislação.

A segunda tese estabelece que as federações tendem a apresentar mais pontos de veto no processo decisório do que os sistemas unitários (Tsebelis, 1997; Weaver e Rockman, 1993), aumentando assim a influência de grupos contrários às iniciativas de reforma (Immergut, 1996). Adicionalmente, as federações criariam instituições específicas para proteger as unidades constituintes de tentativas futuras de expropriação por parte do centro ou de outras unidades, tornando os gover- 
nos subnacionais veto players decisivos em matérias que afetem diretamente seus interesses (Rodden, 2006). Além do bicameralismo, dificuldades para emendar a Constituição, exigências de supermaiorias, referendos, arenas adicionais de veto propiciariam tais poderes de veto (Immergut, 1996; Lijphart, 1999; Obinger, Castles e Leibfried, 2005:8 e ss; Skocpol, 1992). Coalizões supermajoritárias ou condições excepcionais seriam fatores necessários para alterar uma dada distribuição original de competências. Portanto, esses resultados dependem criticamente do modo como instituições que criem oportunidades de veto às minorias se combinam nos contextos nacionais (Pierson, 1995; Gibson, 2004).

As duas teses permitem formular hipóteses explicativas para as mudanças no status quo federativo ocorridas no Brasil. A primeira permite atribuí-las à conversão de um governo central limitado (ou fraco) para iniciar legislação em um governo central forte, com base na superação de obstáculos de ordem jurisdicional. Um governo central, impedido pela Constituição de legislar sobre determinadas áreas, teria aprovado emendas constitucionais transferindo autoridade jurisdicional para o governo federal (Quadro 1, trajetória T1). Essa conversão - de fraco para forte - também poderia ter ocorrido pela superação da "armadilha da decisão conjunta" ${ }^{\prime \prime}$, em que um governo central com poderes jurisdicionais amplos está limitado pelo poder de veto dos governos subnacionais (Quadro 1, trajetória T2). Nessa trajetória, governos anteriores ao governo de controle apresentariam taxas de fracasso parlamentar superiores às dos governos posteriores à alteração das regras.

Assim, se os formuladores da CF 88 desenharam instituições federativas orientadas para constranger a União - isto é, para tornar o governo federal fraco -, as matérias legislativas aprovadas nos anos 1990 só podem ser explicadas por fatores institucionais se o governo federal tiver sido bem-sucedido em T1, em T2 ou em ambas (ver Quadro 1).

Alternativamente, é possível que a explicação para as mudanças nos anos 1990 não seja institucional. Isto é, é possível que elas resultem de um contexto - excepcional - de coincidência de preferências entre as elites do governo central e as elites subnacionais (ou, pelo menos, parte expressiva destas). Nesse caso, os governos subnacionais contariam com poder institucional de veto, mas este não foi exercido ${ }^{4}$. Assim, uma explicação institucional para a legislação aprovada em 1995 su- 


\section{Quadro 1}

Contextos Institucionais de Mudança em Estados Federativos

\begin{tabular}{|c|c|c|}
\hline \multirow{2}{*}{$\begin{array}{l}\text { Oportunidades Insti- } \\
\text { tucionais de Veto }\end{array}$} & \multicolumn{2}{|c|}{ Restrições Jurisdicionais às Iniciativas da União } \\
\hline & Sim & Não \\
\hline \multirow{4}{*}{ Sim } & $\begin{array}{l}\text { Governo central limitado para } \\
\text { iniciar legislação }\end{array}$ & $\begin{array}{c}\text { Governo central com autoridade } \\
\text { para iniciar legislação }\end{array}$ \\
\hline & $\mathrm{e}$ & $1>\mathrm{e}$ \\
\hline & \multirow{2}{*}{$\begin{array}{c}\text { alta probabilidade de fracasso } \\
\text { na aprovação } \\
\text { (ex.: Suíça) }\end{array}$} & $\begin{array}{l}\text { alta probabilidade de fracasso } \\
\text { na aprovação }\end{array}$ \\
\hline & & (ex.: Alemanha pós-1949) \\
\hline \multirow{4}{*}{ Não } & $\begin{array}{l}\text { Governo central limitado para } \\
\text { iniciar legislação }\end{array}$ & $\begin{array}{l}\text { Governo central com autoridade } \\
\text { para iniciar legislação }\end{array}$ \\
\hline & \multirow{3}{*}{$\begin{array}{l}\text { alta probabilidade de sucesso na } \\
\text { aprovação } \\
\text { (ex.: Estados Unidos pré-1930) }\end{array}$} & e \\
\hline & & $\begin{array}{l}\text { alta probabilidade de sucesso na } \\
\text { aprovação }\end{array}$ \\
\hline & & (Brasil pós-1988) \\
\hline
\end{tabular}

Elaboração da autora.

põe distinguir efeitos de instituições dos efeitos das preferências dos atores aos quais se atribui poder de veto.

É plausível supor ainda que a explicação para as mudanças no status quo federativo não sejam derivadas da conversão de um governo central fraco em um governo central forte, caso as regras do jogo estabelecidas em 1988 já tivessem colocado a União no quadrante inferior direito do Quadro 1, o que significa que o governo federal não foi obrigado a se deslocar de uma situação de constrangimento institucional para obter aprovação para sua agenda. Diferentemente, as mudanças no status quo federativo seriam compatíveis com processos de dependência da trajetória em que elites políticas se apoiam em vantagens competitivas, derivadas de espaços políticos previamente ocupados, para obter permanente superioridade sobre seus concorrentes (Pierson, 2004:71 e ss). Nesse caso, as elites políticas de um governo central já forte teriam aumentado sua capacidade de regular as ações dos governos subnacionais, porque a União não teve de obter autorização constitucional para iniciar legislação de interesse direto dos governos subnacionais (como seria o caso na Suíça) nem o Executivo federal teve de reunir supermaiorias para aprovar essa legislação (como seria o caso na Alemanha).

Essas hipóteses são bastante simples e podem ser testadas empiricamente. Para examiná-las, é preciso investigar se a centralização dos 
anos 1990 é explicada por (a) mudanças nos poderes jurisdicionais da União; (b) mudanças nas iniciativas do Executivo federal; (c) mudanças nas oportunidades de veto postas pelas instituições federativas ou, finalmente, por (d) mudanças nas preferências dos atores com poder de veto.

\section{DEFINIÇÕES E PROCEDIMENTOS DE ANÁLISE}

Este artigo pretende identificar os fatores institucionais que tornam possível à União aprovar legislação que afete (mesmo que negativamente) interesses dos governos subnacionais no Brasil. Para isso, foram selecionadas para análise todas as iniciativas legislativas de interesse federativo - envolvendo matérias relativas à distribuição de autoridade em questões de tributação, gastos e encargos -, submetidas à votação na Câmara dos Deputados, do governo Sarney (posteriormente à aprovação da CF 88) ao primeiro governo Luiz Inácio Lula da Silva: no total, 59 iniciativas legislativas que tramitaram pelo Congresso entre 1989 e 2006.

Em um segundo passo, o conteúdo de cada iniciativa legislativa foi examinado com base nas análises do projeto original, dos debates em plenário e da decisão final, em consulta aos Diários da Câmara dos Deputados. Essa análise permitiu classificar as 59 iniciativas de acordo com o tipo de interesse dos governos subnacionais afetado por seu conteúdo, a saber:

(a) matérias que afetaram as receitas de Estados e municípios;

(b) matérias em que a legislação federal afeta a autonomia decisória dos governos subnacionais na arrecadação de seus próprios impostos;

(c) matérias em que a legislação federal afeta a autonomia decisória dos governos subnacionais no exercício de suas próprias competências;

(d) matérias em que a legislação federal afeta a autonomia decisória dos governos subnacionais para decidir sobre a alocação de suas próprias receitas.

O Quadro 2 apresenta essas matérias classificando-as segundo o tipo de interesse federativo afetado, bem como segundo seu efeito sobre as deliberações da CF $88^{5}$. Esse quadro nos permite constatar que essa análise agregada envolve matérias em relação às quais não seria de se 
esperar a mobilização de veto por parte dos governos subnacionais, tal como sugerido por Desposato (2004:279). A classificação por tipo de assunto permite identificar quais unidades constituintes eram afetadas pelas medidas (quarta coluna do Quadro 2) e testar hipóteses relativas a seu (provável) interesse de veto. Além disso, essa seleção abrangente $^{6}$ visou evitar o risco de um viés de seleção pela variável dependente, frequentemente associada aos estudos de caso, permitindo avaliar a inteira variação da variável dependente (King, Keohane e Verba, 1994:115 e ss).

O terceiro passo da análise consistiu em testar empiricamente as hipóteses apresentadas anteriormente, isto é, se a legislação aprovada é explicada por (i) mudanças na distribuição jurisdicional de autoridade, por (ii) mudanças nas oportunidades institucionais de veto dos governos subnacionais ou ainda por (iii) mudanças nas estratégias dos principais atores, quais sejam: o presidente, os governadores ou as bancadas estaduais na Câmara dos Deputados. Para controlar os resultados pelas mudanças nas iniciativas do presidente, foram examinados todos os governos posteriores à aprovação da Constituição Federal de 1988, ou seja, governos Itamar Franco, Fernando Henrique Cardoso I e II, e Luiz Inácio Lula da Silva I ${ }^{7}$. Por fim, para controlar os resultados por mudanças no comportamento dos atores, foi examinado o comportamento das bancadas estaduais nas votações nominais na Câmara dos Deputados. Para tanto, foi mensurada a coesão de cada bancada estadual com base no índice de Rice ${ }^{8}$, bem como suas taxas de disciplina partidária ${ }^{9}$ em relação à orientação de voto do governo ${ }^{10} \mathrm{e}$ em relação aos respectivos governadores ${ }^{11}$. Note-se que o objetivo desta seção consiste em examinar se ocorreram mudanças no comportamento dessas variáveis ao longo de todo o período, a fim de testar empiricamente sua coincidência temporal com as mudanças na variável dependente ${ }^{12}$.

\section{QUE DE FATO MUDOU NOS ANOS 1990?}

Nesta seção, é analisado o conteúdo da legislação aprovada a partir de 1989, visando identificar em que medida as mudanças reverteram a distribuição original de autoridade sobre a arrecadação de tributos, a implementação de políticas públicas, a autoridade sobre gastos, assim como sobre as receitas dos governos subnacionais. Essa análise foi realizada com base na distinção conceitual entre responsabilidades na execução de políticas e autoridade decisória sobre tais competências, em linha 


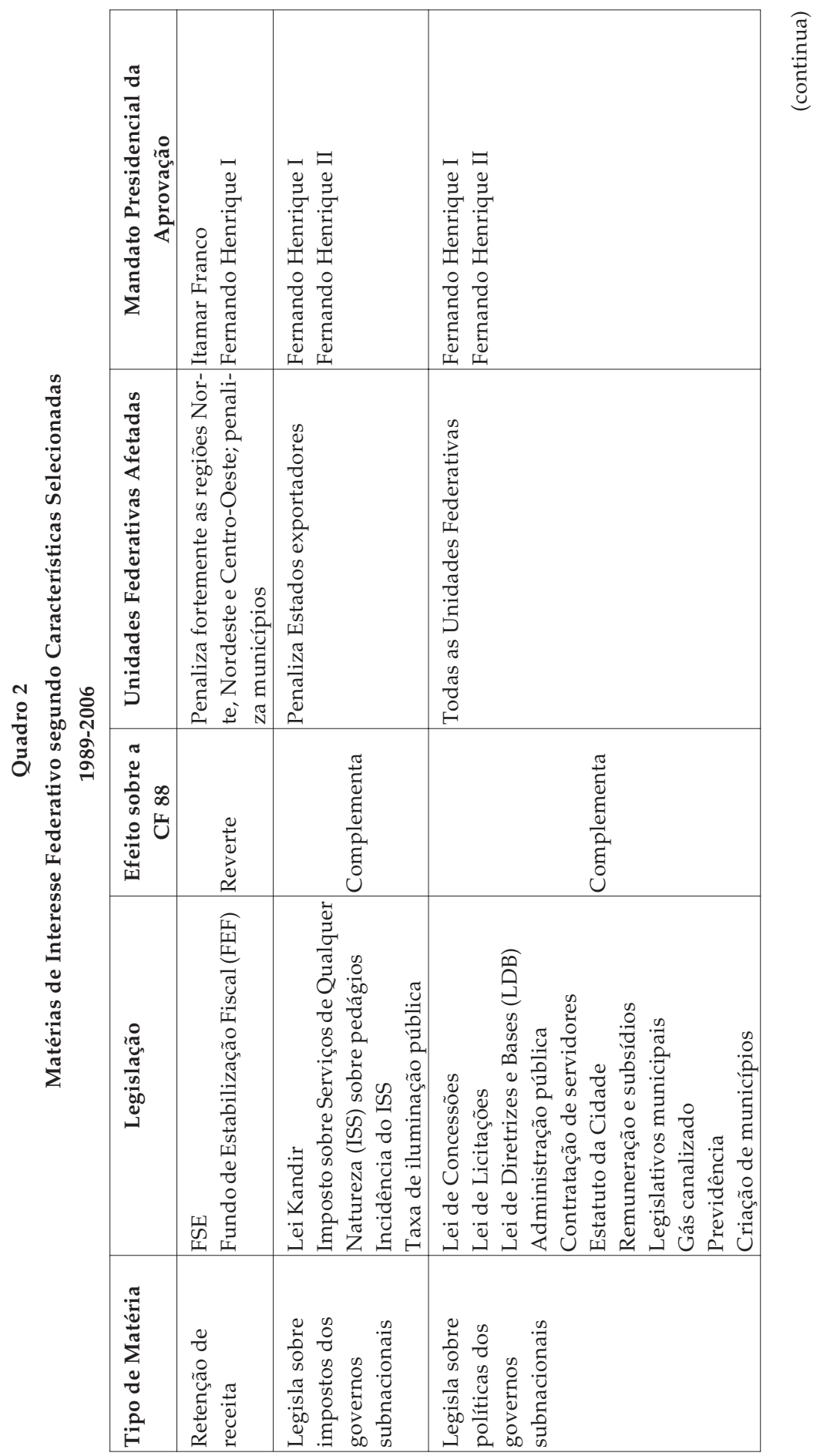


Continuidades e Descontinuidades da Federação Brasileira...

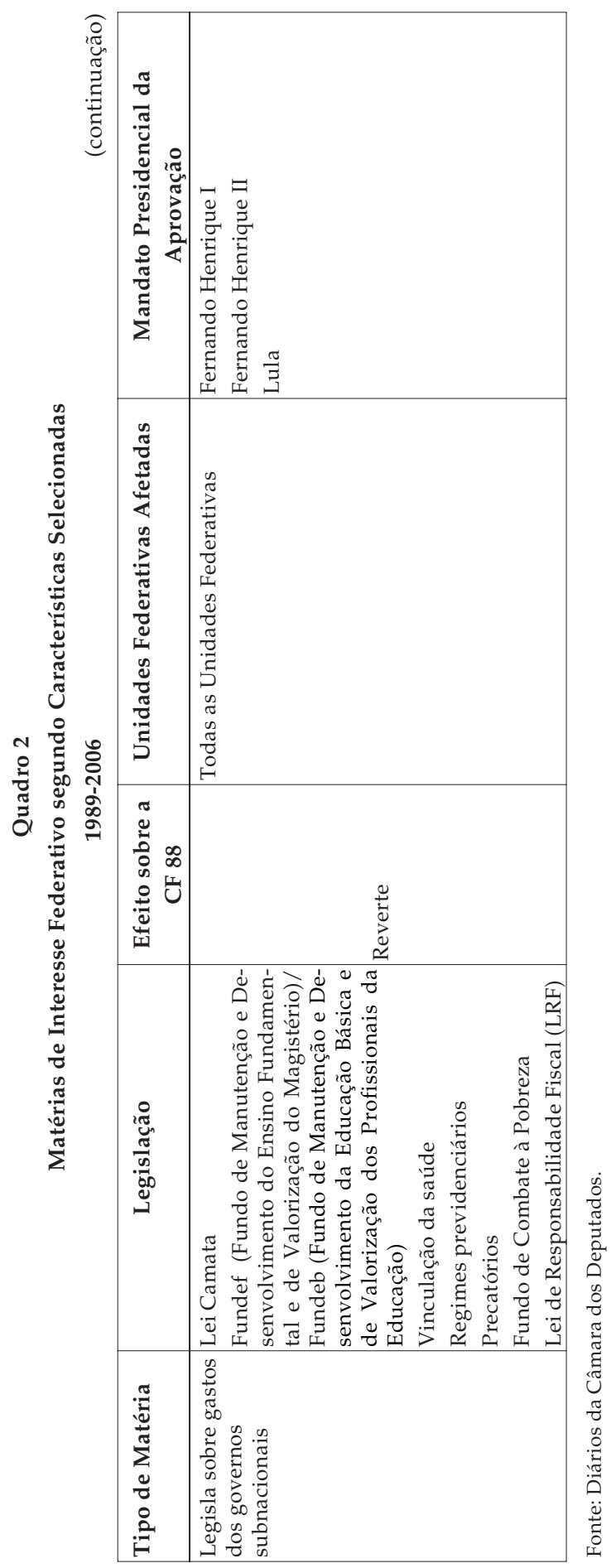


com os modelos adotados por Chibber e Kollman (2004), Stegarescu (2005) e Sellers e Lidström (2007). São analisados, portanto, os quatro tipos de matéria de interesse federativo descritos no Quadro 2.

A aprovação do FSE, até a DRU (Desvinculação de Receitas da União), passando pelo FEF, afetou negativamente as receitas de estados e municípios. Para fazer seu próprio ajuste fiscal, o governo federal reverteu decisões da CF 88 por meio de duas medidas combinadas: (a) flexibilização das alíquotas que vincularam receitas da União a destinos específicos de gasto; e (b) retenção de parte das transferências constitucionais a Estados e municípios. Essa última revertia uma das mais reconhecidas medidas descentralizadoras da CF 88, pois reduziu o montante de receitas tributárias que a União é obrigada a transferir para Estados e municípios. As medidas afetaram, portanto, as receitas de todas as unidades federativas, mas seu maior impacto foi sobre as regiões Norte, Nordeste e Centro-Oeste, bem como sobre os municípios pequenos, sabidamente mais dependentes das transferências constitucionais.

A flexibilização dos gastos vinculados da União - pela retenção prévia de $20 \%$ do total da arrecadação de todos os impostos e contribuições da União - foi sucessivamente aprovada em todas as edições da medida, período que vai do governo Itamar ao governo Lula. Entretanto, a retenção de $20 \%$ das transferências constitucionais encontrou crescentes dificuldades de aprovação parlamentar, o que levou o presidente Fernando Henrique a um recuo desse componente da estratégia já em sua reedição de 1999. A primeira edição do FSE - aprovada no governo Itamar Franco - foi a mais dura do ponto de vista da imposição de perdas a Estados e municípios, visto que combinou simultaneamente a desvinculação de gastos da União, a elevação da alíquota da Contribuição Social sobre o Lucro Líquido (CSLL) e a retenção de parte das receitas dos fundos constitucionais por um período de dois anos. As edições posteriores do FSE prorrogaram o Fundo por um período mais reduzido caso da reedição de 1996 - ou foram acompanhadas de regras (também) constitucionais de ressarcimento (ainda que parcial) das perdas fiscais de Estados e municípios - caso da reedição de $1997^{13}$.

No entanto, ainda que essas decisões tenham envolvido concessões, o saldo líquido foi amplamente favorável à União. Embora a aprovação dessas medidas tenha envolvido intensas negociações, todos os presidentes - de Itamar a Lula - conseguiram aprovar a reedição do 
FSE / FEF/DRU, e as concessões feitas foram residuais quando comparadas aos ganhos da União.

As matérias em que a União legislou sobre impostos estaduais e municipais foram aprovadas no governo Fernando Henrique. Trata-se da aprovação da Lei Kandir e da autorização para que os municípios incluíssem as tarifas de pedágio na cobrança do ISS e instituíssem taxas de iluminação pública. A Lei Kandir impôs perdas importantes de receita aos Estados exportadores ${ }^{14}$, ao passo que as tarifas de pedágio ampliaram a base tributária dos municípios. Contudo, a aprovação dessas leis não apenas não alterou a distribuição de autoridade tributária prevista na CF 88 como de fato representou a continuidade das disposições dessa Constituição.

A Lei Kandir ficou conhecida como a lei que desonerou as exportações e os produtos semielaborados da incidência do ICMS. Entretanto, teve um alcance muito mais amplo, pois foi discutida na Câmara dos Deputados como a lei que unificou todas as normas de arrecadação do ICMS, envolvendo inclusive as regras pelas quais os Estados devolveriam a quota-parte de seus próprios municípios. Para os parlamentares, na Câmara dos Deputados, a Lei Kandir veio resolver uma "ausência" de normatização da CF 88, que havia atribuído "provisoriamente" aos Estados a autoridade para normatizar a cobrança do ICMS, pois o Ato das Disposições Constitucionais Transitórias havia determinado que o ICMS fosse regulado por uma lei complementar "federal"15. Assim, a aprovação dessa lei em nada alterou a distribuição jurisdicional de autoridade tributária da Constituição de 1988, que já previa que a legislação que regula a arrecadação do ICMS deveria ser federal. Na verdade, os formuladores da CF 88 conceberam uma modalidade de distribuição vertical de autoridade tributária que centraliza, na União, a prerrogativa de definir as normas de arrecadação e a base de incidência dos impostos estaduais e municipais. Essa centralização é a contrapartida necessária da homogeneidade dessas regras no território nacional.

O mesmo princípio regeu a tramitação legislativa dos impostos municipais. Crédulos da propalada tese de que se haviam convertido em entes federativos autônomos e que tinham autonomia sobre seus próprios impostos, muitos municípios ampliaram a cobrança de ISS sobre os pedágios e instituíram taxas de iluminação pública. As concessionárias das estradas recorreram ao Supremo Tribunal Federal (STF), que 
lhes deu ganho de causa com base no argumento de que o art. $156 \mathrm{da} C \mathrm{CF}$ 88 estabelecia que uma lei complementar deveria fixar as alíquotas e os serviços incluídos na cobrança do ISS.

Observe-se, portanto, que a interpretação do STF - instância que desempenha o papel de Suprema Corte para conflitos federativos no Brasil - foi de que caberia à União definir o que é passível de cobrança nos impostos sob tributação exclusiva dos municípios. Se uma determinada base de incidência não está prevista na lei federal, o município não pode taxá-la. Somente após a aprovação da lei complementar no 100/1999, as prefeituras puderam cobrar ISS sobre as tarifas de pedágio.

Trajetória semelhante teve a aprovação da cobrança da taxa municipal de iluminação pública. À credulidade dos prefeitos em suas prerrogativas tributárias correspondeu o acolhimento do STF dos recursos que não autorizavam sua cobrança. Nesse caso, o art. 145 (CF 88) não autorizava a incidência de taxas sobre a base de impostos. Mais que isso, o fato de que cobrança das taxas tivesse sido autorizada por meio de uma lei ordinária foi derrubada no STF por inconstitucionalidade, sendo, portanto, necessária a aprovação de uma emenda constitucional para autorizar os municípios a cobrarem essa taxa ${ }^{16}$.

O processo decisório dessas matérias pôde, assim, ser interpretado com base na teoria do poder jurisdicional. Não apenas o governo federal não estava impedido de legislar sobre essas matérias como estava na verdade autorizado pela CF 88 a iniciar esse tipo de legislação. $\mathrm{Na}$ verdade, a Constituição de 1988 limitou os governos subnacionais a adotar novas bases de tributação sem prévia autorização da legislação federal. Longe de ser fraco para legislar sobre matérias desse tipo, o governo federal estava instado a fazê-lo. É por essa razão que, como veremos adiante, a maior parte dessa legislação tramitou sob a forma de projetos de lei complementar.

Os governos do presidente Fernando Henrique aprovaram extensa produção legal, em que a União legislou sobre as competências de Estadose municípios. Foram aprovadas, entre outras, leis tão importantes quanto a Lei de Concessões, a LDB, a reforma administrativa, o Estatuto da Cidade. Em conjunto, essa legislação disciplina o modo como Estados e municípios devem exercer as competências que lhes foram atribuídas pela CF $88^{17}$. Essa legislação estabelece regras homogêneas para todos os governos subnacionais, detalhando o modo como devem exercer suas próprias competências. Longe de representar uma reversão 
do contrato original firmado em 1988, essa centralização decisória em nada contraria os dispositivos estabelecidos por seus formuladores, representando, na verdade, sua continuidade ${ }^{18}$.

A Constituição de 1988 havia previsto competências privativas da União em políticas a serem executadas por Estados e municípios. Essa decisão revela que os constituintes não apenas não pretenderam limitar a União em sua autoridade para legislar sobre as ações de Estados e municípios como lhe autorizaram exclusividade para legislar sobre políticas que estavam, nesse mesmo contexto, sendo transferidas para Estados e municípios.

Essa extensão da autoridade regulatória da União poderia ter gerado uma reação de defesa da autonomia dos governos subnacionais na medida em que fortalecia o controle exercido pelo governo federal. Mais que isso, poderia ter dado origem a uma ampla coalizão de veto, uma vez que afetava negativa e simultaneamente a autonomia decisória de Estados e municípios.

Nos dois mandatos do presidente Fernando Henrique, a aprovação de matérias em que a União limita a autonomia decisória dos gastos estaduais e municipais revela que esse tema veio para o centro da agenda de governo. Essa legislação, de fato, representou uma mudança importante em relação às deliberações da CF 88, que conferia ampla autonomia de gasto a Estados e municípios, excetuada a área de ensino. A aprovação dessa legislação significou substancial redução da autonomia decisória dos governos estaduais e municipais sobre a alocação de suas próprias despesas.

Além da Lei Camata, apenas o Fundef foi aprovado no primeiro mandato de Fernando Henrique. Seu segundo mandato, contudo, foi extremamente ativo na aprovação da legislação que vinculou receitas de Estados e municípios à saúde; obrigou Estados e municípios a criarem fundos de combate à pobreza; determinou as condições e os prazos de pagamento de precatórios; estabeleceu tetos para o gasto dos legislativos municipais, bem como com pessoal ativo e inativo; regulou os regimes previdenciários, além de criar restrições ao endividamento e à expansão do gasto ${ }^{19}$.

As emendas constitucionais de fato não apenas reverteram os princípios de autonomia de gasto da CF 88 como também legislaram com detalhe a 
alocação dos gastos dos governos subnacionais, autorizando a intervenção da União caso esses dispositivos não fossem cumpridos.

Entretanto, parte dessa agenda de ordenamento das finanças dos governos subnacionais estava dando continuidade às deliberações da Constituição de 1988. Em seus arts. 163 e 169, a CF 88 remeteu para lei complementar federal a definição das normas das finanças públicas e os limites de despesa com pessoal ativo e inativo. Assim, os conteúdos da LRF e da Lei Camata não estavam previstos pelos constituintes, mas a regulamentação federal das finanças subnacionais não apenas não foi negada pelo contrato original como era esperado que assim o fosse.

Em suma, nos anos 1990, as elites do governo central foram muito bem-sucedidas em aprovar extensa legislação federal, que fortaleceu a autoridade da União sobre Estados e municípios na medida em que essa legislação regulou extensivamente o modo como os governos subnacionais arrecadavam seus impostos exclusivos, implementavam as políticas sob sua responsabilidade e gastavam seus próprios recursos. A noção de que essa legislação teria representado uma ruptura radical em relação ao contrato original de 1988 obscurece, contudo, os elementos de continuidade entre 1988 e 1995 . Ruptura e continuidade estiveram presentes nas deliberações dos anos 1990. Ruptura em relação à autonomia subnacional sobre gastos, mas continuidade de um modelo de Estado federativo que confere autoridade à União para regular o modo como Estados e municípios devem executar suas próprias competências sobre impostos, políticas e gastos. A legislação federal dos anos 1990 não inaugurou um novo modelo de Estado federativo. Seus princípios normativos já estavam presentes na Constituição de 1988.

\section{DE COMO 1988 FACILITOU 1995: DETERMINANTES INSTITUCIONAIS DAS MUDANÇAS}

Nesta seção, são examinados os determinantes institucionais da legislação aprovada nos anos 1990 cujo conteúdo afetou negativamente as receitas, bem como a autoridade sobre impostos, políticas e gastos dos governos subnacionais. A seção anterior e o Quadro 2 revelam que a maior parte dessa legislação foi aprovada durante o governo Fernando Henrique Cardoso, confirmando o que demonstraram diversos autores (Abrucio e Costa, 1999; Samuels e Mainwaring, 2004; Melo, 2005), embora os governos Itamar Franco e Luiz Inácio Lula da Silva também tenham aprovado medidas de conteúdo similar. Entretanto, para iden- 
tificar os fatores que explicam o sucesso parlamentar dos presidentes, é necessário dar um passo adicional à identificação do presidente cujo mandato concentrou matérias legislativas aprovadas. É preciso testar empiricamente se a ausência de medidas aprovadas está associada ao fracasso parlamentar dos presidentes anteriores (hipótese do governo central fraco) ou, alternativamente, se essa ausência se deve ao fato de os presidentes anteriores não iniciarem esse tipo de legislação. Em segundo lugar, para testar a hipótese de que o sucesso parlamentar de Fernando Henrique se deveu a uma atualização do cálculo político dos governadores, causando comportamento cooperativo das bancadas estaduais no Congresso, é preciso testar empiricamente se esse comportamento não foi cooperativo com os presidentes anteriores.

\section{As Preferências dos Presidentes}

Os governos Fernando Collor de Mello e Itamar Franco foram extremamente tímidos para submeter ao Congresso matérias de interesse federativo. Collor não partilhava a preferência pelo modelo descentralizado de execução de políticas públicas aprovado na CF 88. Na verdade, pretendeu reverter esse modelo. Nomeou para ministro da Saúde um ex-dirigente do Instituto Nacional de Assistência Médica da Previdência Social (Inamps) e vetou 25 artigos da Lei Orgânica da Saúde, aprovada por unanimidade na Câmara dos Deputados (Arretche, 2004). Além disso, a agenda política do segundo ano de seu mandato esteve fortemente ocupada por seu impeachment. É difícil precisar a agenda da ampla coalizão de sustentação do curto e tempestuoso mandato de Itamar Franco, embora a LDB, a Lei de Concessões e a primeira - e mais dura - versão do FSE tenham sido aprovadas em seus dois anos de mandato. Sua gestão como governador de Minas Gerais, no entanto, autoriza a duvidar que Itamar tivesse claras preferências por um modelo de Estado federativo em que a União exercesse sua autoridade para regular as políticas e os gastos dos governos subnacionais ${ }^{20}$.

O senador Fernando Henrique Cardoso, ao contrário, já havia apresentado, em 1991, um projeto de lei que disciplinava as concessões de serviços públicos em todos os níveis de governo, cuja proposta original já revelava sua preferência por um modelo de Estado federativo compatível com aquele adotado pelos constituintes em 1988.

A regulação dos impostos, das políticas e dos gastos dos governos subnacionais esteve no centro da agenda do presidente Fernando Henri- 
Gráfico 1

Iniciativas Legislativas por Presidente e Tipo de Interesse Federativo

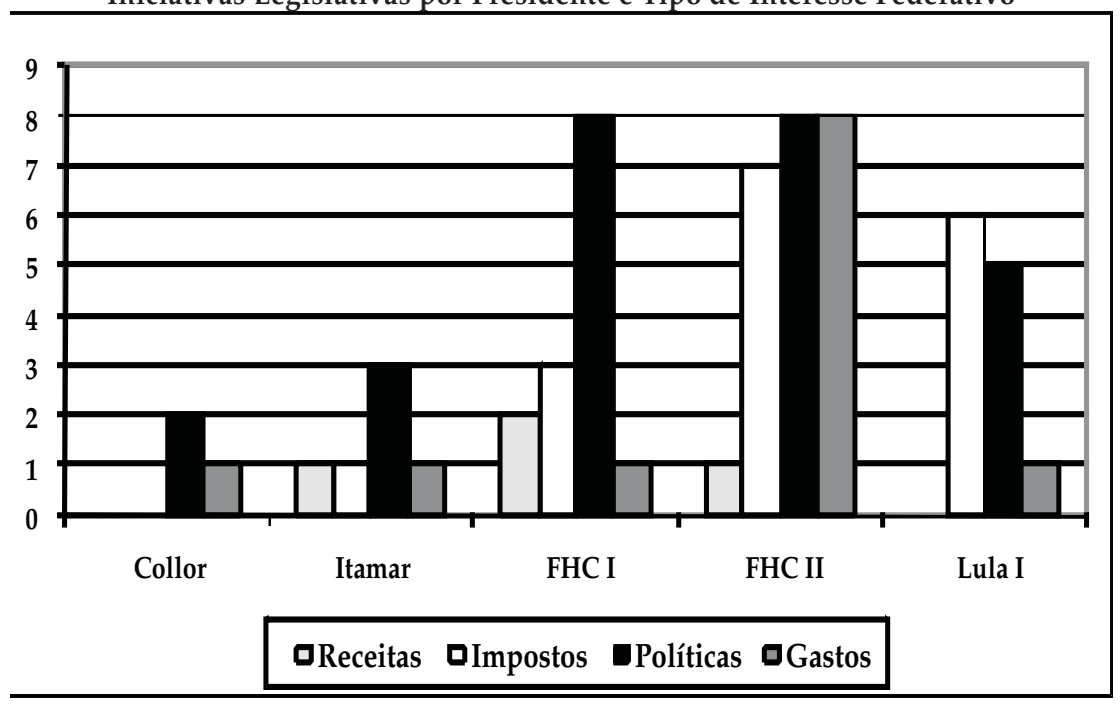

Fonte: Diários da Câmara dos Deputados.

que. Seus dois mandatos foram bem mais ativos do que os de seus antecessores na proposição de matérias legislativas desse tipo (ver Tabela $1^{21}$ ). Das 59 matérias desse estudo, quatorze tramitaram no Congresso em seu primeiro mandato contra apenas três no governo Fernando Collor e seis no governo Itamar. Seu segundo mandato foi ainda mais ativo do que o primeiro, tendo submetido à votação 24 matérias que afetavam os interesses de Estados e municípios.

Essa mudança na agenda da presidência pode ser mais bem observada no Gráfico 1. Para qualquer uma das matérias examinadas, o Congresso foi chamado para deliberar sobre um maior número de iniciativas legislativas durante os mandatos de Fernando Henrique Cardoso. Seu primeiro mandato deu prioridade à regulação das políticas executadas por Estados e municípios, ao passo que, durante seu segundo mandato, o Congresso foi chamado para deliberar sobre a regulação federal dos impostos, das políticas e dos gastos dos governos subnacionais.

Fernando Collor e Itamar Franco não obtiveram fracasso parlamentar em suas iniciativas. A Câmara dos Deputados aprovou todas as matérias votadas durante os governos Collor, Fernando Henrique e Lula I, tendo rejeitado apenas uma matéria votada no governo Itamar (ver Tabela 1). 
Continuidades e Descontinuidades da Federação Brasileira...

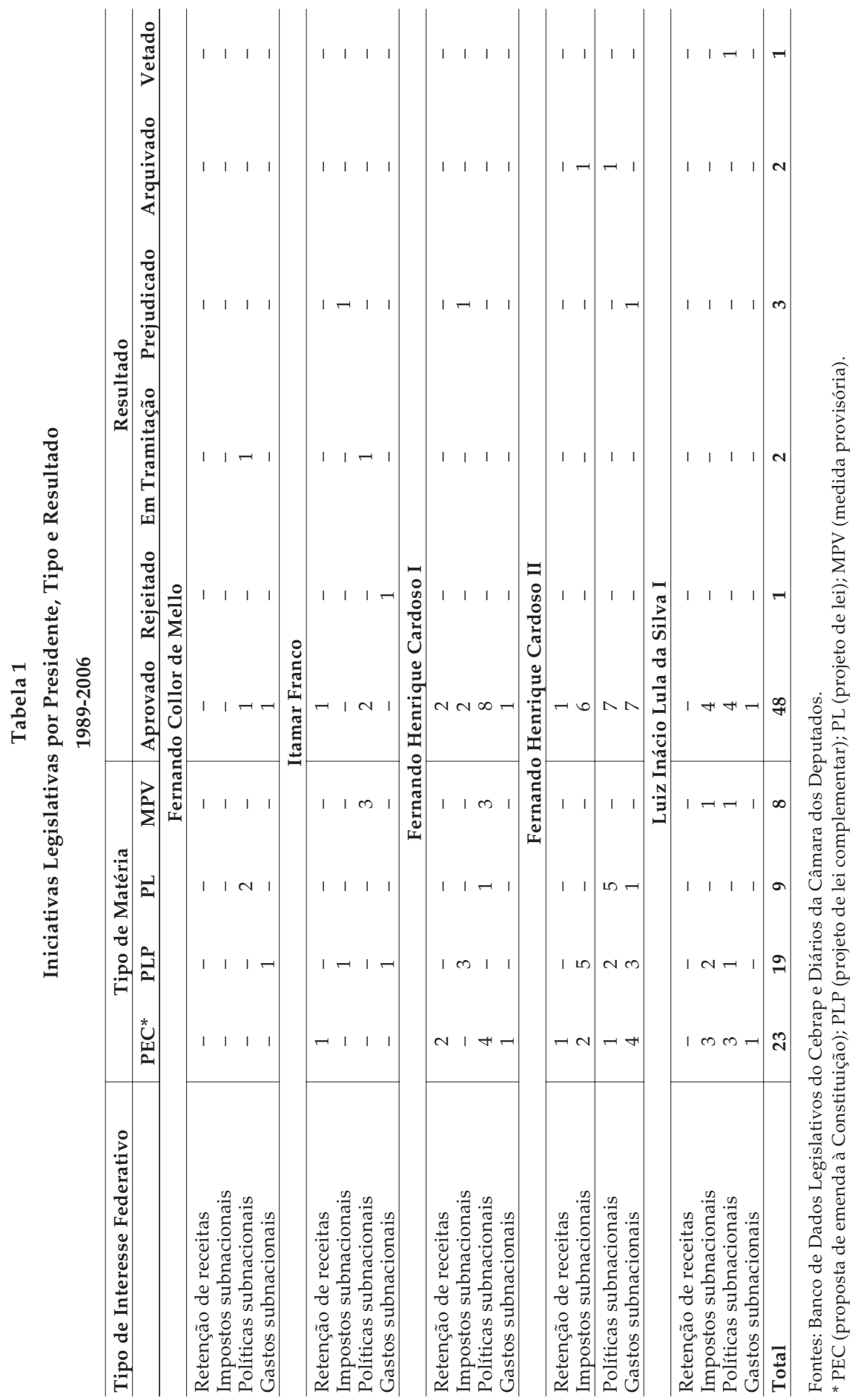


Pode-se argumentar, corretamente, que essas medidas quantitativas são excessivamente cruas, por considerarem equivalentes matérias de relevância e conteúdo muito distintos. Não se pode afirmar, contudo, que a Lei de Concessões, a Lei Camata, a Lei de Licitações e a LDB sejam irrelevantes; e foram aprovadas nos governos Collor e Itamar quando submetidas à votação. Portanto, não há evidência empírica de que o fortalecimento da regulação federal no governo Fernando Henrique tenha sido precedido de fracasso parlamentar dos presidentes anteriores. O fato é que Fernando Collor e Itamar Franco tiveram muito poucas iniciativas para regular os governos subnacionais. Em suma, as mudanças institucionais ocorridas a partir de 1995 são parcialmente explicadas pela mudança na agenda da presidência, não havendo evidências de fracasso parlamentar dos presidentes anteriores e posteriores a Fernando Henrique Cardoso.

\section{Mudanças no Comportamento das Bancadas Estaduais}

As 59 matérias totalizaram 450 votações nominais. Foram excluídas vinte votações inválidas - aquelas em que não houve quórum para votação - e 131 votações unânimes - aquelas em que todas as lideranças partidárias tiveram a mesma orientação de voto $^{22}$-, razão pela qual não é possível determinar a fidelidade dos parlamentares. Restam, portanto, 308 votações nominais para as quais é possível examinar a coesão e a fidelidade dos parlamentares por bancada estadual.

Em todos os gráficos desta seção, as bancadas estaduais estão ordenadas da esquerda para a direita pelo índice de Rice ${ }^{23}$. Assim, caso a bancada estadual votasse de modo coeso, esse índice seria próximo de cem. Caso contrário, se a bancada estadual estivesse rigorosamente dividida, seria próximo de zero ${ }^{24}$. As demais medidas avaliam a disciplina dos parlamentares em relação à orientação de voto de seu respectivo líder partidário, à orientação de voto do líder do governo e à orientação de voto do líder do partido a que pertence o governador do respectivo Estado.

No governo Fernando Collor (Gráfico 2), foram aprovadas a Lei de Concessões e a Lei Camata, além do primeiro turno da Lei de Licitações (ver Tabela 1 do Anexo). Portanto, essas matérias limitavam a autoridade de todos os governos subnacionais, indistintamente, sobre suas próprias políticas e seus próprios gastos. A despeito disso, as bancadas estaduais não vetaram as propostas, visando defender a autonomia de 
Gráfico 2

Fidelidade e Coesão das Bancadas Estaduais na Câmara dos Deputados

Governo Fernando Collor de Mello

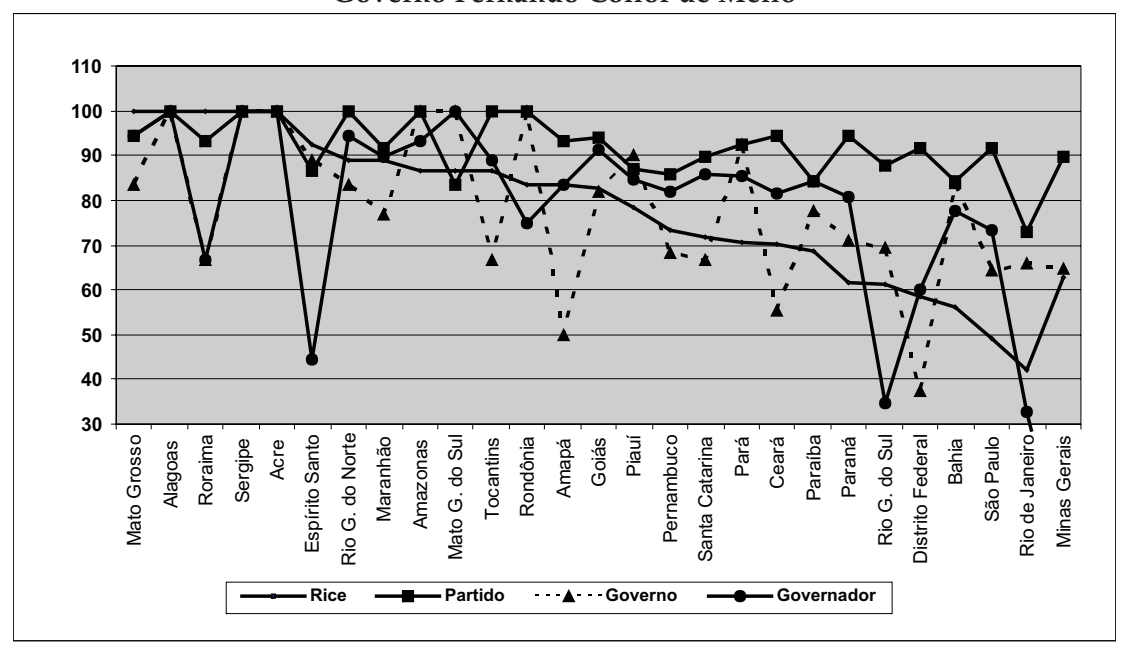

Fonte: Banco de Dados Legislativos do Cebrap.

gasto e de contratação de seus governadores e prefeitos. Em apenas um caso (Distrito Federal), a maioria da bancada votou contra o governo. Isso significa que, caso governadores e prefeitos tenham sido contrários a essas medidas, não foram capazes de mobilizar suas bancadas para vetar a medida. Mais que isso, o voto contrário à orientação do líder do governo não pode ser creditado à orientação do governador, pois o comportamento regular dos parlamentares foi de fidelidade à orientação dos líderes partidários (observe-se que a taxa de fidelidade ao respectivo líder partidário é sistematicamente superior àquela que mede a fidelidade ao partido do governador). Isso significa que, quando os parlamentares não votam com o líder do governo - isto é, não cooperam com o presidente -, esse resultado é explicado pela dificuldade de o presidente obter apoio dos partidos, em particular do $\mathrm{PMDB}^{25}$.

No governo Itamar Franco (Gráfico 3), foram votadas a Lei de Licitações, a LDB, uma lei de autoria do senador Fernando Henrique que excluiria as exportações do (então) Imposto sobre Serviços de Qualquer Natureza (ISSQN), um projeto de lei que criaria um sistema nacional de educação tecnológica e um projeto de lei complementar que criaria uma aposentadoria especial para os profissionais de saúde de todos os níveis de governo, além da versão mais dura do FSE, que "expropria- 
Gráfico 3

Fidelidade e Coesão das Bancadas Estaduais na Câmara dos Deputados

Governo Itamar Franco

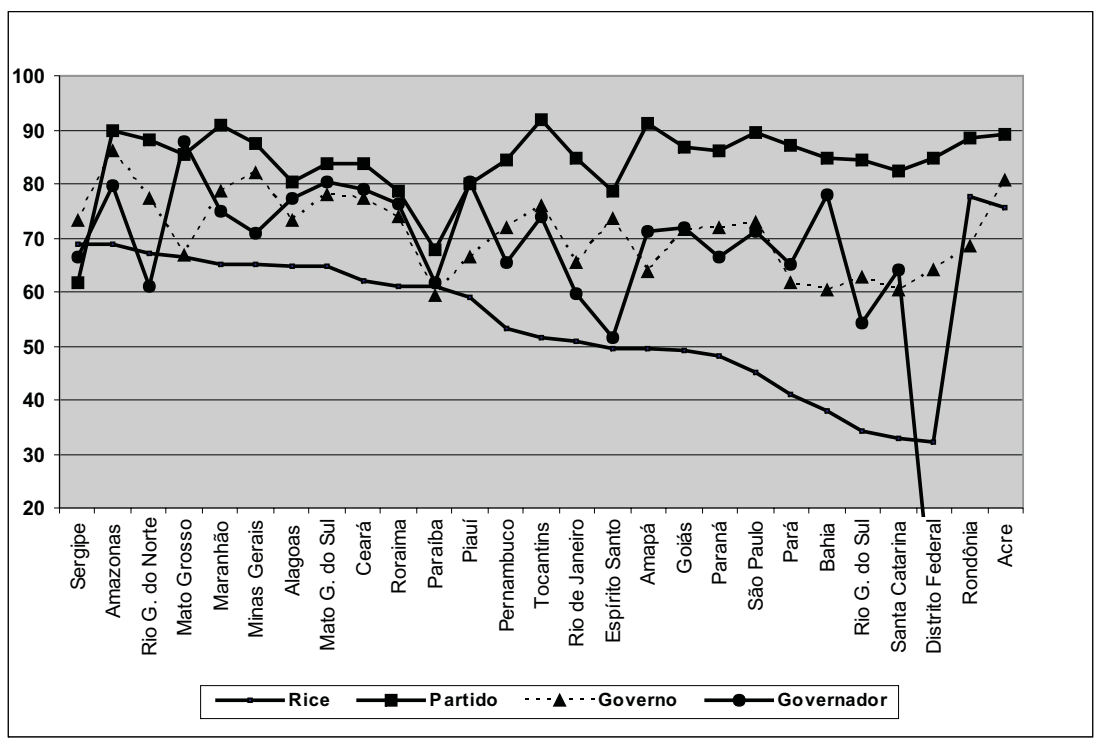

Fonte: Banco de Dados Legislativos do Cebrap.

va" 20\% das transferências constitucionais a Estados e municípios (ver Tabela 1 do Anexo). Portanto, as medidas votadas afetavam tanto a autonomia decisória dos governos subnacionais sobre suas próprias políticas quanto receitas dos Estados mais pobres da federação e dos municípios pequenos, sabidamente dependentes das transferências federais.

A despeito disso, em todos os estados, a maioria dos parlamentares votou favoravelmente à orientação de voto do líder do governo. Assim, o plausível interesse de veto dos "perdedores" - governadores dos Estados das regiões Norte, Nordeste e Centro-Oeste - não se traduziu em voto contrário da maioria dos representantes das bancadas desses Estados. Os governadores não tiveram capacidade de comando superior à dos líderes partidários nessas votações, visto que (com exceção de Sergipe) a taxa de fidelidade à orientação de voto do líder partidário foi superior à taxa de fidelidade à orientação de voto do partido do governador.

No governo Fernando Henrique Cardoso I (Gráfico 4), foram votadas tanto medidas que suprimiam receitas de Estados e municípios (como 
Gráfico 4

Fidelidade e Coesão das Bancadas Estaduais na Câmara dos Deputados Governo Fernando Henrique Cardoso I

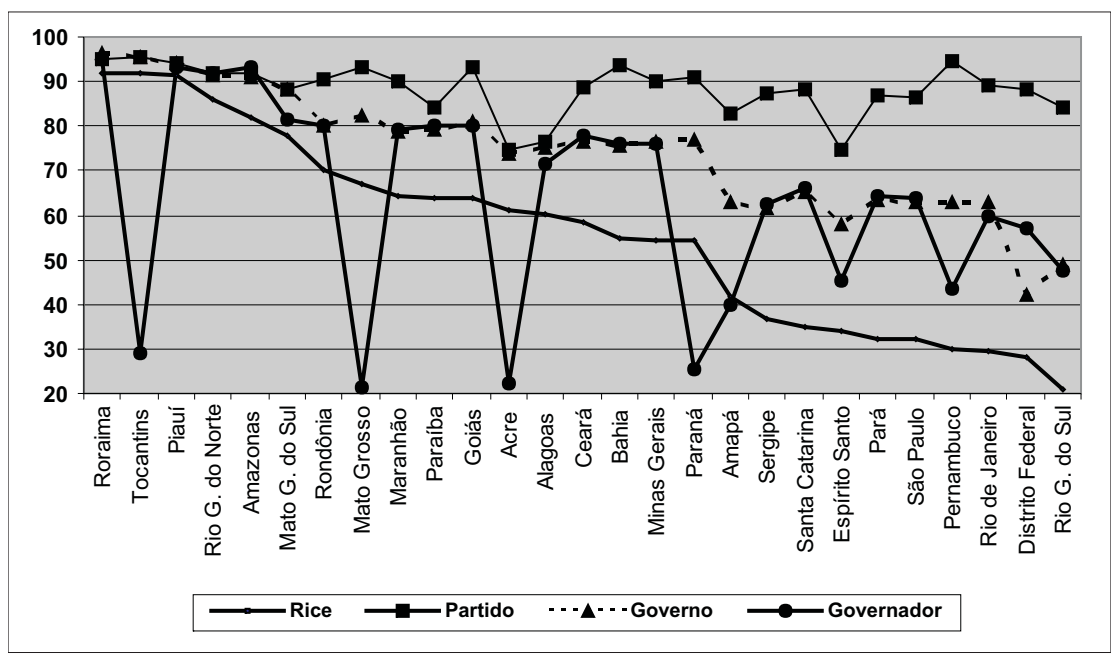

Fonte: Banco de Dados Legislativos do Cebrap.

o FSE e a Lei Kandir) quanto iniciativas legislativas que disciplinaram o modo como os governos territoriais arrecadariam seus próprios tributos (Lei Kandir), exerceriam suas próprias competências (Lei de Concessões, previdência, capítulo da Administração Pública, LDB) e gastariam suas próprias receitas (Fundef). Portanto, o conteúdo das propostas votadas na Câmara dos Deputados, no governo Fernando Henrique, não é substancialmente distinto daquele votado durante os mandatos dos presidentes anteriores.

Entretanto, não há evidência de que os fatores que permitiram o sucesso parlamentar dos presidentes anteriores sejam distintos dos observados para o governo Fernando Henrique. Esse sucesso não pode ser interpretado como derivado de uma estratégia de apresentação de propostas não polêmicas que tenha obtido apoio porque foi capaz de antecipar o voto contrário de bancadas potencialmente hostis. As matérias que tramitaram no Congresso foram majoritariamente caracterizadas pela "imposição de perdas" aos governos territoriais, em particular nos mandatos do presidente Fernando Henrique. A retenção das transferências constitucionais reverteu, por um período de cinco anos, 20\% das receitas automáticas de Estados e municípios, penalizando mais 
fortemente os estados do Norte, Nordeste e Centro-Oeste, e os pequenos municípios, ou seja, unidades subnacionais às quais se atribui o poder de veto de minorias sobrerrepresentadas no Congresso. A Lei Kandir penalizou as receitas dos Estados exportadores - unidades subnacionais às quais se atribui poder de veto associado à sua importância econômica na federação. A limitação da autonomia decisória das unidades federativas sobre seus próprios gastos afetou negativamente todos os governos subnacionais. A Lei de Responsabilidade Fiscal (LRF), bem como um conjunto de outras leis, ampliou a extensão em que a União normatiza o modo como Estados e municípios executam suas próprias políticas e recolhem seus próprios impostos, afetando todos os membros da federação (Quadro 1). Em suma, o conjunto de medidas impôs perdas a todos os tipos de minoria subnacional aos quais a literatura tem atribuído poderes de veto para impedir sua aprovação.

Além disso, na tramitação da maior parte desses projetos, a oposição utilizou extensivamente o argumento do ataque às prerrogativas dos governos subnacionais para impor custos políticos à coalizão de sustentação do presidente. A despeito disso, o comportamento das variáveis que estamos analisando é basicamente o mesmo para todos os presidentes: da mesma forma que para os governos anteriores, a maioria dos parlamentares de cada Estado apoia as iniciativas do governo federal, sendo sua fidelidade à orientação de voto dos líderes partidários que explica esse comportamento.

Nos grandes Estados, agora comandados por governadores do mesmo partido do presidente - a saber, São Paulo, Minas Gerais e Rio de Janeiro-, as bancadas apresentam taxas de coesão inferiores a $60 \%$, indicando que pelo menos $20 \%$ dos parlamentares presentes não votaram de acordo com a maioria da bancada. Na verdade, em média, $40 \%$ dos parlamentares das bancadas de São Paulo e Rio de Janeiro que compareceram às votações votaram contra a orientação de voto do líder do governo. Portanto, não é possível creditar o sucesso parlamentar do presidente na aprovação dessas medidas ao apoio dos governadores de seu partido. Nem sequer é possível creditar esse sucesso exclusivamente ao apoio dos governadores.

Como já apontado anteriormente, o segundo governo Fernando Henrique foi extremamente ativo na aprovação de um pacote de medidas que (i) disciplinou a arrecadação dos impostos municipais, definindo as bases de incidência do ISS; (ii) disciplinou as finanças públicas esta- 
duais e municipais, com a aprovação da LRF; (iii) reverteu a autonomia de gasto dos governos subnacionais prevista na CF 88, com a aprovação dos Fundos de Combate à Pobreza, da vinculação de gasto com saúde, da legislação que rege o pagamento de precatórios e os gastos dos legislativos municipais, bem como (iv) definiu como os governos municipais exerceriam suas próprias competências, com a aprovação do Estatuto da Cidade.

É razoável esperar que governadores e prefeitos mobilizassem seus representantes para vetar essas matérias. No entanto, como se pode observar, caso o tenham feito, não obtiveram sucesso, pois o voto favorável é, em média, superior a $60 \%$ em cada bancada estadual. Não há evidências que autorizem afirmar que o apoio dos governadores tenha sido essencial para o sucesso legislativo do governo Fernando Henrique II. Observe-se que as taxas de fidelidade à orientação de voto do partido do governador são as mais baixas para quase todas as bancadas estaduais (Gráfico 5).

Nesse segundo mandato, o PSDB perdeu as eleições em Minas Gerais e no Rio de Janeiro, ficando no comando do Estado de São Paulo, que tem a maior bancada do país. Entretanto, observe-se que São Paulo apresentou uma das mais baixas taxas de coesão, acompanhada de uma elevada taxa de fidelidade partidária, isto é, a bancada paulista estava rigorosamente dividida - situação indicada pelo fato de as taxas

\section{Gráfico 5}

Fidelidade e Coesão das Bancadas Estaduais na Câmara dos Deputados Governo Fernando Henrique Cardoso II

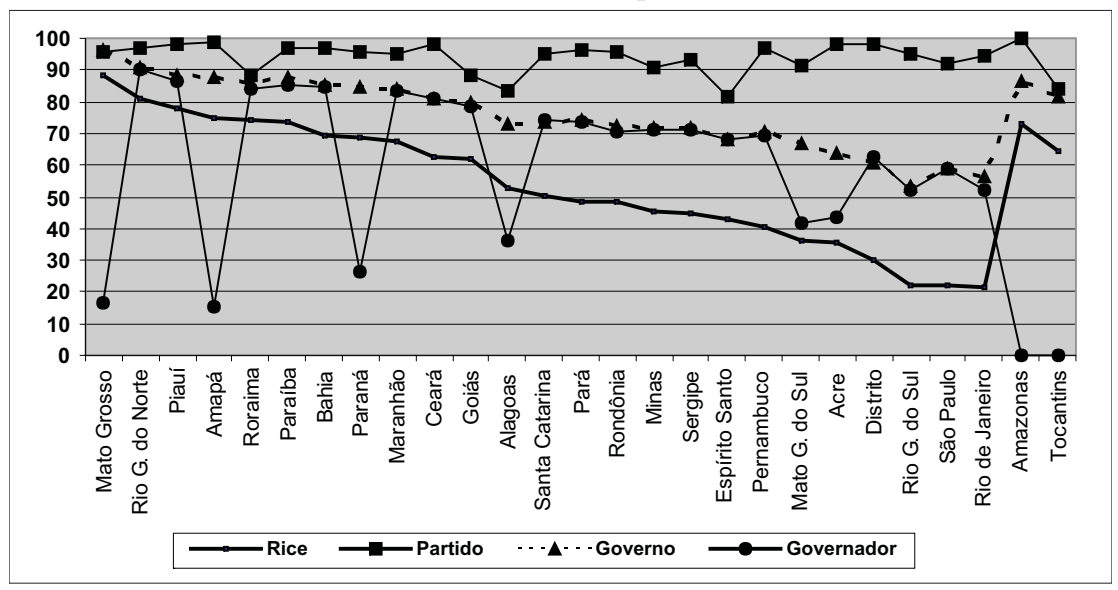

Fonte: Banco de Dados Legislativos do Cebrap. 
de fidelidade ao líder do governo e ao partido do governador estarem em torno de $50 \%$. Observe-se que o comportamento da bancada do Rio de Janeiro é bastante similar, embora o governador não fosse do partido do presidente. Na verdade, o fato de o comportamento sistemático das bancadas estaduais apresentar taxas de fidelidade partidária próximas de $100 \%$ indica que os conflitos em torno dessas matérias foram processados em termos partidários, o que significa que os parlamentares dos partidos de oposição tenderam predominantemente a não votar com o governo. Em outras palavras, os governadores do partido do presidente não parecem ter obtido o voto favorável dos parlamentares da oposição.

No governo Lula I (Gráfico 6), foi votada a DRU, que teria como efeito reduzir o montante das transferências voluntárias a Estados e municípios, e foram aprovadas a legislação que disciplinaria os regimes previdenciários de Estados e municípios, a contratação de agentes de saúde, as Parcerias Público-Privadas e o Fundeb. O conteúdo dessas matérias, bem como o fato de que muitos Estados eram comandados por governadores da oposição, não impediu o presidente de aprovar essas medidas, visto que, para todas as bancadas, o voto favorável foi supe-

\section{Gráfico 6}

Fidelidade e Coesão das Bancadas Estaduais na Câmara dos Deputados Governo Luiz Inácio Lula da Silva I

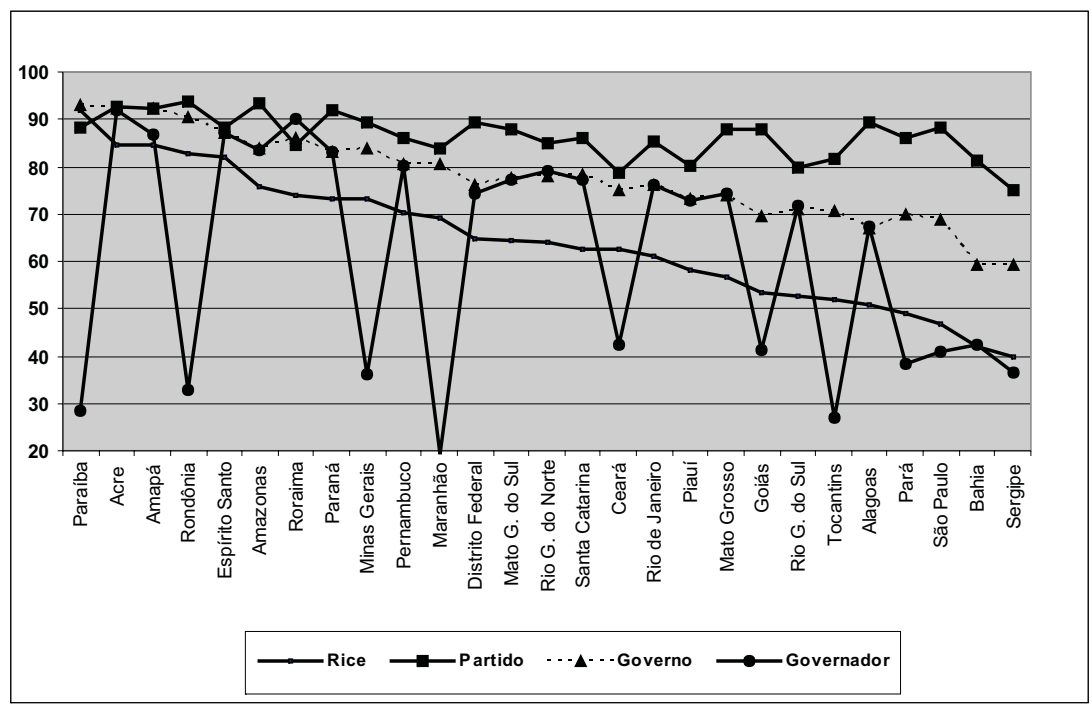

Fonte: Banco de Dados Legislativos do Cebrap. 
rior a $60 \%$. Mais uma vez, é a fidelidade dos parlamentares a suas respectivas lideranças partidárias que explica o sucesso parlamentar do presidente na aprovação dessas medidas.

Em suma, o comportamento das bancadas estaduais na votação de matérias de interesse federativo não parece ter apresentado alteração significativa no período pós-1988. Desse modo, não se pode atribuir o fato de os mandatos de Fernando Henrique Cardoso terem concentrado a aprovação dessas matérias a uma mudança no comportamento das bancadas estaduais em relação ao presidente. Assim, embora os governadores possam ter atualizado seu cálculo político no que tange à sua relação com o presidente, essa mudança não parece ser a causa do sucesso parlamentar de Fernando Henrique. Em primeiro lugar, porque, como também demonstraram Cheibub, Figueiredo e Limongi (2006; 2009), não há evidências robustas de que os governadores tenham maior poder de comando sobre o voto dos parlamentares do que os líderes partidários. Em segundo lugar, porque as matérias que foram à votação na Câmara dos Deputados obtiveram apoio da maioria das bancadas estaduais, a despeito de seu conteúdo de "imposição de perdas". Na verdade, a mudança ocorrida no governo Fernando Henrique Cardoso diz respeito à agenda do presidente, esta, sim, concentrada em fortalecer a capacidade de regulação do governo federal sobre os governos subnacionais.

\section{INSTITUIÇÕES FEDERATIVAS E PODER DE VETO}

Resta examinar por que a tramitação dessas matérias é essencialmente um jogo entre o presidente, as bancadas estaduais e os partidos políticos no Congresso. Requer explicação o fato de as matérias de interesse federativo serem processadas nesses termos. Isso diz respeito às regras estabelecidas pela CF 88 para processar as interações futuras entre as unidades da federação.

\section{A Autoridade Jurisdicional da União}

Os formuladores da Constituição não parecem ter pretendido limitar as iniciativas legislativas da União. No mesmo ato com que aprovaram um modelo de Estado federativo que transferia competências sobre a ехеcução de políticas para os governos subnacionais, aprovaram dispositivos constitucionais que davam ampla autoridade à União para legislar sobre essas mesmas políticas. Também não parecem ter preten- 
dido construir um Estado federativo em que os governos subnacionais tivessem autoridade exclusiva para legislar e executar suas próprias políticas. Longe de criar uma federação com um centro limitado, conferiram amplos poderes jurisdicionais à União.

É, de certo modo, surpreendente que esse aspecto tenha sido pouco explorado pela literatura, a despeito da centralidade do federalismo na agenda de pesquisas sobre as instituições políticas brasileiras. De fato, em muitos países - federativos, bem como unitários -, a disputa entre jurisdições é um elemento central dos conflitos sobre a produção de políticas públicas (Obinger et alii, 2005:266 e ss; Moore, Jacoby e Gunlicks, 2008).

ACF 88 (no art. 21) lista 25 áreas de competência da União, que incluem as políticas de comunicação, de infraestrutura, de desenvolvimento urbano, de energia e de transporte, além de "elaborar e executar planos nacionais e regionais de ordenação do território e de desenvolvimento econômico e social". Assim, já em 1988, a União estava autorizada a legislar sobre todas as políticas estratégicas, mesmo que estas fossem implementadas pelos governos subnacionais. Além disso, o art. 22 lista 29 áreas de competência privativa da União, que incluem políticas que seriam executadas por Estados e municípios, tais como: todas as áreas do direito, águas, energia, telecomunicações, radiodifusão, transportes, emprego, polícias militares, seguridade social, diretrizes da educação, assim como normas de licitação e contratação (ver Quadro 3). Somadas, essas áreas representam 56 itens. Ao atribuir sua competência à União, os constituintes limitaram, de fato, a formulação autônoma de políticas por parte dos governos subnacionais.

O art. 24, que conta com apenas 16 incisos, lista as áreas em que as competências são concorrentes, ou seja, aquelas sobre as quais União, Estados e municípios poderiam legislar. Essas áreas incluem o meio ambiente, a educação, a previdência, bem como a assistência à juventude (ver Quadro 3).

Em outros termos: em que área de política pública estava a União impedida de legislar pela CF 88 ? Se a resposta a essa questão listasse a área de desenvolvimento urbano, por exemplo, o Estatuto da Cidade teria sido barrado na Comissão de Constituição e Justiça, por ter a União atravessado uma fronteira de jurisdição. Se a resposta a essa questão envolvesse as normas de contratação de pessoal, o governo federal seria obrigado a adotar a estratégia T1 (no Quadro 1) para apre- 
Continuidades e Descontinuidades da Federação Brasileira...

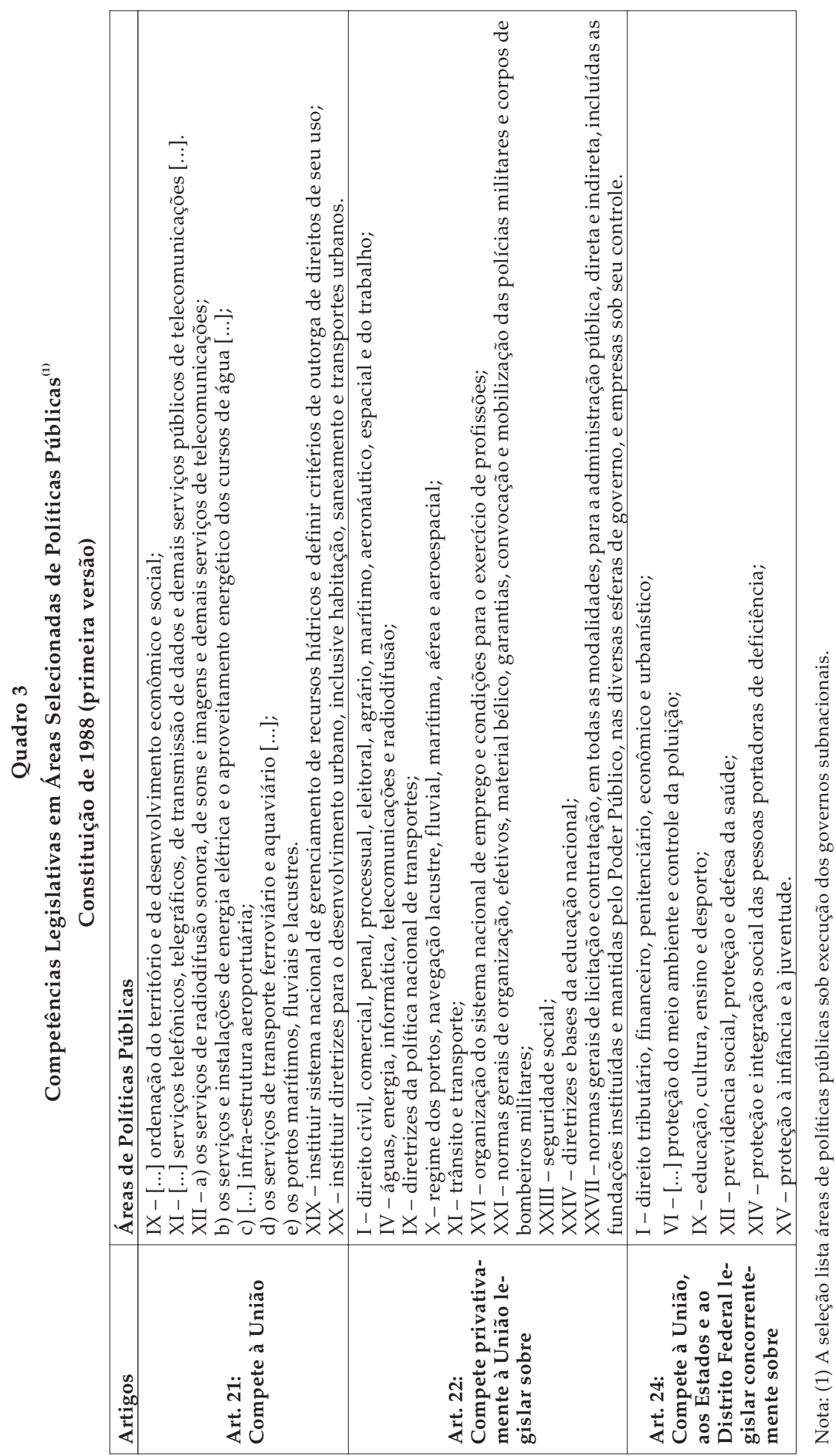


sentar a PEC que tratou do capítulo da Administração Pública. Ou, alternativamente, este teria que ter tido um alcance muito mais limitado, pois não poderia reger as normas de contratação de Estados e municípios. Longe de limitar a União, os legisladores de 1988 conferiram-lhe amplos poderes jurisdicionais.

Além disso, um aspecto pouco observado diz respeito às disposições transitórias da Constituição. A Lei Camata e a LRF, por exemplo, que tiveram um impacto significativo sobre as finanças dos governos subnacionais, estavam baseadas nos arts. 163 e 169 da CF 88, que remetiam para lei complementar federal a definição das normas das finanças públicas e os limites de despesa com pessoal ativo e inativo. A tramitação parlamentar de matérias tão importantes como a Lei Kandir, a Lei de Concessões, a Lei de Licitações, a LDB, o Estatuto da Cidade, o capítulo da Administração Pública e a Lei das Parcerias Público-Privadas não envolveu nenhuma alteração de poder jurisdicional, pois sua apresentação não obrigou a União a atravessar uma fronteira de jurisdição (T1 no Quadro 1). Essas matérias apenas deram continuidade às disposições da Constituição.

Em resumo, as preferências dos constituintes já haviam sido no sentido de atribuir à União autoridade para legislar sobre as regras segundo as quais Estados e municípios arrecadariam seus próprios tributos, bem como as regras segundo as quais os governos subnacionais executariam parte importante das políticas descentralizadas.

Os constituintes poderiam, entretanto, ter produzido um modelo de Estado federativo que produzisse sistematicamente joint-decision traps (Scharpf, 1988), caso tivessem combinado ampla autoridade jurisdicional da União com exigências de supermaiorias para aprovação de matérias de interesse federativo. Examinemos, portanto, se as regras previstas pelos constituintes para reger as interações futuras entre as unidades constituintes exigiam supermaiorias para aprovar mudanças no status quo federativo.

\section{Poderes Institucionais de Veto dos Governos Subnacionais}

O contrato original de 1988 não previu nenhum processo decisório distinto para matérias legislativas que envolvam o status quo federativo. Isto é, iniciativas legislativas que afetam interesses dos entes federativos têm as mesmas regras de tramitação que qualquer outro tipo de matéria nas arenas legislativas federais. Portanto, os formuladores da Constituição não parecem ter previsto instituições políticas que impu- 
sessem proteções especiais às iniciativas de revisão da distribuição original de competências de 1988.

\section{Emendas à Constituição}

De 1989 a 2006, foram aprovadas 53 emendas constitucionais. Destas, 28 disseram respeito a matérias de interesse federativo. Esse resultado significa uma taxa anual de emendamento de 3,5. Em termos internacionais, essa taxa é muito superior à dos países que adotaram estratégias restritivas para aprovação de emendas à Constituição. Nestes, a taxa é igual ou inferior a 1,3 (Lutz, 1994) ${ }^{26}$. Se medirmos apenas as matérias de exclusivo interesse federativo, a taxa anual seria de 1,8, ainda assim superior à taxa geral de aprovação de emendas constitucionais dos países que adotam estratégias restritivas de emendamento, segundo o modelo adotado por Lutz.

Das 59 matérias examinadas (ver Tabela 1), 23 - portanto, pouco mais de um terço - eram propostas de emenda constitucional, o que confirma a interpretação de que a agenda legislativa pós-1988 envolveu revisões constitucionais (Melo, 2002; Couto e Arantes, 2006). Entretanto, o fato de a CF 88 requerer alterações futuras - considerando sua extensão - não é condição suficiente para explicar sua elevada taxa de emendamento posterior. Em outros termos, a necessidade de emendar a Constituição não explica o sucesso do emendamento. De fato, como demonstrado por Lutz (1994), constituições extensas e detalhadas apresentam altas taxas de emendamento quando esse fator está combinado com regras que facilitam a aprovação das emendas. Em outros termos, o fato de que tenham sido aprovadas 21 emendas constitucionais que afetaram o status quo federativo - das 23 PECs com esse conteúdo votadas na Câmara dos Deputados - revela que não há obstáculos institucionais de grande monta para aprovar emendas constitucionais no Brasil, mesmo quando seu conteúdo "expropria direitos das unidades constituintes".

Embora a aprovação de emendas constitucionais seja a modalidade mais exigente de alteração no status quo da legislação brasileira, esta é comparativamente pouco exigente em termos internacionais (Arretche, 2002; 2008). Os constituintes de 1988 optaram por requerer dois turnos de votação, na Câmara dos Deputados e no Senado, da mesma legislatura. Nesses termos, a incerteza em relação à obtenção de maioria na segunda votação é praticamente zero. A opção pela regra de maioria 
parlamentar também foi a mais baixa em termos internacionais, de apenas três quintos. Assim, não são necessárias supermaiorias para aprovar emendas à Constituição, visto que uma maioria de $60 \%$ em quatro sessões relativamente próximas permite alterar a Carta.

Além disso, federações que buscaram criar oportunidades de veto para emendar a Constituição instituíram arenas adicionais de decisão ${ }^{27}$. No Brasil, diferentemente, a formação de uma coalizão majoritária nas arenas decisórias centrais é condição suficiente para emendar a Constituição. Nesse caso, aprovada uma emenda constitucional pelo Congresso, ela passará a ter imediata validade para todos os entes federativos sem que estes tenham uma nova oportunidade institucional de veto. São essas regras que permitem que o jogo "comece e termine" como essencialmente um jogo entre o presidente, as bancadas estaduais e os partidos no Congresso.

Em suma, os formuladores da Constituição não parecem ter pretendido exigir que fossem necessárias supermaiorias para que mudanças na CF 88 fossem aprovadas. Nem pretenderam oferecer oportunidades de veto aos opositores de reformas pela via de uma multiplicidade de arenas decisórias. Ao contrário, desde 1988, as oportunidades de veto dos governos territoriais foram pensadas como limitadas na medida em que estão concentradas, nas arenas decisórias centrais, em uma mesma legislatura. Assim, um presidente que consiga reunir uma coalizão majoritária e estável nas duas casas legislativas terá grandes chances de aprovar emendas à Constituição, mesmo que estas afetem negativamente os interesses dos governos territoriais. Em outras palavras, minorias têm limitadas oportunidades institucionais de veto desde o contrato original de 1988.

\section{Disposições Constitucionais, Poder Jurisdicional e Poder de Veto}

Um aspecto ainda pouco explorado das mudanças no status quo federativo diz respeito ao fato de que essas mudanças não envolveram apenas emendas à Constituição. Como já mencionado, matérias tão importantes como a Lei Kandir, a Lei Camata e a LRF foram, na origem, projetos de lei complementar. Como declarou o relator da Lei Kandir, o deputado Luiz Carlos Hauly (PSDB-PR), em uma das citações no início deste artigo, os formuladores da CF 88 haviam conferido provisoriamente aos Estados a autoridade para normatizar a cobrança do ICMS até que uma 
lei complementar federal o fizesse. Igualmente, a Lei Camata e a LRF também foram amparadas em disposições do mesmo tipo.

É certo que os formuladores da CF 88 não haviam previsto qual seria o conteúdo dessa legislação, mas já haviam atribuído à União a competência para legislar sobre as finanças subnacionais. As deliberações sobre essas matérias não envolveram, portanto, recentralização da autoridade na União, mas sim continuidade e desenvolvimento de decisões da Assembleia Constituinte.

Mais que isso, ao conferir à União a autoridade para dar continuidade à elaboração da Constituição em matérias dessa natureza, os constituintes não pretenderam exigir supermaiorias para sua aprovação. Projetos de lei complementar podem ser iniciados em qualquer uma das casas legislativas - Câmara dos Deputados ou Senado. A casa revisora pode apresentar emendas; mas, em caso de aprovação, a casa iniciadora não precisa aceitá-las, ainda que, nesse caso, o projeto deva retornar à casa iniciadora. Além disso, é necessária a maioria dos membros das duas casas tanto para a votação nominal quanto para a aprovação. Se houver aprovação nas duas casas, um projeto de lei complementar pode ser aprovado por $51 \%$ dos membros em um turno de votação.

Assim, desde o contrato original em 1988, as elites do governo central não tinham diante de si a difícil tarefa de reunir supermaiorias em uma multiplicidade de pontos de veto para aprovar matérias tão importantes quanto a LRF, por exemplo. Na verdade, um projeto de lei complementar tem as exigências mínimas de formação de maioria absoluta. Em outras palavras, para vetar a LRF, a minoria não contava com muitas oportunidades de veto.

Pode-se argumentar, corretamente, que muitas disposições transitórias das constituições brasileiras permanecem letra morta. Entretanto, o argumento apresentado aqui não é que essa legislação foi iniciada porque a CF assim o exigiu. Diferentemente, o argumento sustenta que as disposições transitórias não impediram que as elites do governo central iniciassem esse tipo de matéria. Ou melhor, as disposições transitórias permitiram que a agenda de governo federal, que visava regular as finanças e as políticas dos governos subnacionais, tenha sido apresentada e processada sob condições institucionais que facilitaram sua aprovação parlamentar, bem como limitaram as oportunidades de veto dos governos subnacionais. 
Matérias tão importantes quanto a LDB, o Estatuto da Cidade, a Lei de Concessões, a Lei de Licitações e as Parcerias Público-Privadas puderam tramitar sob a forma de projetos de lei. Isso porque legislavam sobre políticas que, embora executadas por Estados e municípios, eram de competência exclusiva da União. Essas matérias, portanto, não envolveram recentralização decisória ou supressão de prerrogativas dos governos subnacionais. Envolveram apenas a deliberação sobre questões que, desde a CF 88, estavam previstas como matérias em que a União deveria legislar. Em outras palavras, puderam tramitar sob essa forma porque não exigiram que a União tivesse que adotar a estratégia T1 (Quadro 1) para legislar sobre essas matérias.

O poder jurisdicional da União, nesses casos, facilita significativamente sua aprovação, bem como limita o veto dos governos subnacionais. Projetos de lei não exigem nem sequer maioria absoluta para aprovação. Sua tramitação é semelhante à dos PLPs, isto é, a casa iniciadora não está obrigada a incorporar mudanças apresentadas pela casa revisória. Em outras palavras, se a casa revisora não rejeitar o projeto, a maioria nas duas casas é suficiente para aprovação de um projeto de lei. Este pode ser aprovado pela maioria simples dos presentes na sessão e por votação simbólica. A minoria pode exigir, no máximo, uma votação nominal para aprovação do requerimento de urgência. Resta, portanto, para a oposição, unicamente a estratégia de tornar visível a responsabilidade pela decisão, tentando impor custos eleitorais à aprovação de medidas de imposição de perdas. No entanto, as oportunidades de veto das minorias são bastante limitadas.

Em suma, a combinação dos poderes jurisdicionais com as regras que regem o processo decisório em matérias de interesse federativo fornece amplas oportunidades de iniciativa e aprovação parlamentar às matérias iniciadas pelas elites do governo central. Na verdade, são as elites dos governos subnacionais que têm suas oportunidades de veto restringidas a reunir maiorias oposicionistas na Câmara dos Deputados, casa em que se inicia a maior parte das iniciativas legislativas. A única estratégia de veto consiste em reunir uma maioria oposicionista no Senado ou na Câmara dos Deputados. O jogo tem grandes chances de terminar se o presidente conseguir reunir uma coalizão majoritária baseada nos partidos que lhe dão sustentação no Congresso. 


\section{CONCLUSÕES}

Os formuladores da Constituição de 1988 combinaram ampla autoridade jurisdicional à União com limitadas oportunidades institucionais de veto aos governos subnacionais. Assim, formularam um desenho de Estado federativo em que os governos subnacionais têm responsabilidade pela execução de políticas públicas, mas autorizaram a União a legislar sobre suas ações. Além disso, formularam regras que permitem que a maioria, nas arenas decisórias centrais, aprove mudanças no status quo federativo. Em suma, a CF 88 não produziu instituições políticas que tornariam o governo central fraco em face dos governos subnacionais.

Os constituintes de 1987-1988 também autorizaram a União a legislar em algumas áreas, privativamente - sobre todas as matérias que dizem respeito às ações de Estados e municípios. Assim, o modelo de Estado federativo brasileiro autoriza as elites do governo central a apresentar iniciativas legislativas em todas as áreas relevantes de políticas públicas, em particular naquelas cuja execução é de competência de Estados e municípios. Em outras palavras, os formuladores da Constituição atribuíram à União a autoridade para regular as regras de execução das competências dos governos subnacionais - tais como a arrecadação de seus próprios impostos, a seleção de seus próprios governantes e representantes, e a implementação de suas principais políticas. Nesse sentido, limitaram as iniciativas dos governos subnacionais.

Além disso, não criaram muitas oportunidades institucionais de veto às minorias, promovendo requerimentos especiais para aprovação de matérias legislativas que afetem os interesses dos governos subnacionais. Não previram fortes proteções institucionais para evitar que a União tomasse iniciativas para expropriar suas receitas ou mesmo sua autoridade sobre os impostos e as políticas sob sua competência.

Em suma, os formuladores não criaram um ambiente institucional que congelasse a distribuição original de autoridade de 1988, dificultando emendas à Constituição. Adotaram uma das fórmulas mais facilitadoras para mudar a Constituição no leque de regras existentes no mundo. Maiorias de três quintos em duas sessões de cada casa legislativa, na mesma legislatura, são suficientes para alterar as disposições do contrato original. As oportunidades de veto à mudança constitucional se restringem a essas arenas, limitando as oportunidades de veto das minorias. 
Também parecem ter entendido como incompleta a Carta que estavam entregando à nação. Assim, já em sua versão original, indicaram que ela deveria ser complementada por legislação adicional, mas não consideraram que supermaiorias fossem necessárias para aprovação dessa legislação complementar. Em suma, não estabeleceram regras que exigiriam a mobilização de supermaiorias para alterar aquele contrato original.

Desse modo, não criaram instituições federativas que tenham colocado as gerações futuras em joint-decision traps, qual seja, um desenho institucional em que o centro está simultaneamente autorizado a legislar sobre as políticas dos governos subnacionais, mas paralisado por seus poderes de veto. Diferentemente, as instituições que regem as interações entre as elites do governo central e as elites regionais permitem que uma preferência majoritária nas duas casas centrais não encontre obstáculos institucionais para converter-se em política. Preenchida essa condição, são limitadas as oportunidades de veto das minorias.

Na verdade, leis federais que regulem as políticas executadas por Estados e municípios podem até mesmo surgir via projetos de lei ordinária - nas diversas áreas em que a União conta com competências privativas -, cujas regras de aprovação requerem maioria simples dos parlamentares presentes nas sessões para converter-se em leis.

A combinação de um presidente com uma agenda de reformas federativas, apoiado em uma coalizão majoritária, concretizou-se apenas em 1995. São esses fatores que explicam as amplas mudanças no status quo federativo ocorridas desde então. A partir de 1995, as elites do governo central usaram estrategicamente essas oportunidades institucionais para ampliar a capacidade de regulação da União sobre as políticas de Estado e municípios. Essa não foi, portanto, uma trajetória de ruptura de um governo central fraco em direção a um governo central forte. Antes, um centro forte tornou-se ainda mais forte; 1988 facilitou 1995.

A centralização federativa de 1995 ocorreu porque as regras que regem as interações entre as elites do governo federal e dos governos subnacionais favorecem as elites políticas instaladas no centro e limitam as oportunidades de veto das elites instaladas nos governos subnacionais. Desse modo, conflitos entre essas duas categorias de elites governamentais tendem a facilitar a aprovação das preferências das primeiras. Elites políticas instaladas no governo federal tendem a ter suas 
preferências de políticas alavancadas por um centro forte - porque autorizado a legislar sobre as ações de Estados e municípios, e sem necessidade de mobilizar coalizões supermajoritárias de apoio. Assim, há mais continuidade entre as mudanças na estrutura federativa da segunda metade da década de 1990 e o contrato original de 1988 do que a noção de uma ampla reestruturação das relações intergovernamentais autorizaria supor.

Na verdade, as interpretações sobre a CF 88 maximizaram seus aspectos descentralizadores, ignorando inteiramente a extensão em que seus formuladores adotaram princípios centralizadores e mantiveram, na esfera da União, decisões que diziam respeito ao modo como os governos territoriais executariam suas próprias políticas.

As frases que abrem este artigo são complementares. A afirmação do deputado Antonio Geraldo (PFL-BA) - pronunciada por ocasião dos debates parlamentares na tramitação da PEC no 41/1991, que restringiu a autoridade dos Estados sobre a criação de municípios -, bem como a afirmação do deputado Luiz Carlos Hauly (PSDB-PR) - relator da Lei Kandir -, é reveladora da continuidade entre preferências majoritárias na constituinte de 1987-1988 e no processo decisório da segunda metade dos anos 1990, cujo resultado foi tornar mais forte o centro da federação brasileira.

(Recebido para publicação em janeiro de 2009)

(Versão definitiva em abril de 2009) 


\section{NOTAS}

1. Samuels e Mainwaring (2004:86; tradução da autora), por exemplo, descrevem “[...] o federalismo como um jogo de barganhas entre o governo central (o presidente, em particular) e os estados".

2. Neste estudo, "instituições federativas" estão definidas como as "regras que regem mudanças legislativas em matérias que afetam interesses das unidades da federação". Seu emprego aqui tem apenas a finalidade de distinguir a variável dependente - mudanças legislativas - da variável independente - regras do jogo. Esse procedimento tem sido crescentemente empregado pelos autores para contornar o problema de que as análises sobre federalismo não contam com consensos mínimos sobre os termos utilizados, sendo marcadas pela profusão de termos iguais para designar objetos diferentes, bem como pelo emprego de termos diferentes para analisar objetos empíricos semelhantes. A esse respeito, ver Almeida (2001); Gibson (2004); Treisman (2007); e Souza (2008).

3. O conceito de joint-decision trap (Scharpf, 1988) é empregado para descrever contextos institucionais de paralisia decisória derivados da combinação entre centralização jurisdicional da autoridade e poderes de veto dos governos subnacionais.

4. Esta parece ser a interpretação de Abrucio e Costa (1999), para quem os impactos fiscais do Plano Real, bem como a aprovação do Fundo Social de Emergência (FSE), no governo Itamar, quando Fernando Henrique Cardoso era ministro da Economia, teriam afetado negativamente as receitas dos governos territoriais, tornando os governadores mais propensos a cooperar com o Executivo federal. Essa mudança nas preferências dos governadores, por sua vez, explicaria o comportamento cooperativo das bancadas estaduais no Congresso durante o governo Fernando Henrique.

5. No Quadro 2, as políticas listadas envolveram mais de uma iniciativa legislativa. As 59 iniciativas examinadas referem-se apenas aos temas listados no Quadro 1, como pode ser observado na Tabela 1 do Anexo.

6. Foram excluídos desta análise dois tipos de matéria legislativa: (i) aquelas em que o governo federal encaminhou soluções para seus problemas de equilíbrio fiscal via criação de novas fontes de receita, tais como as propostas relativas ao Imposto sobre a Propriedade Territorial Rural (ITR) e à criação do Imposto Provisório sobre Manutenção Financeira (IPMF)/Contribuição Provisória sobre Manutenção Financeira (CPMF) e da Contribuição de Intervenção do Domínio Econômico (Cide); (ii) aquelas que envolveram revisão dos critérios de distribuição das transferências constitucionais entre as unidades federativas.

7. No governo Sarney, nenhuma matéria legislativa que preenchesse todos os critérios da análise foi à votação nominal na Câmara dos Deputados. Assim, não é possível fazer nenhuma afirmação sobre o comportamento parlamentar em matérias de interesse federativo em seu governo.

8. O índice de Rice foi calculado com base na diferença, em cada votação nominal, entre os votos SIM e NÃO da bancada estadual, excluídas as abstenções e faltas.

9. A disciplina partidária foi calculada com base na média de parlamentares de cada bancada que seguiram a orientação de seu respectivo líder partidário para cada votação em que essa indicação ocorreu, excluídas as abstenções e faltas. 
10. A disciplina em relação ao governo foi calculada com base na média de parlamentares de cada bancada estadual que seguiram a orientação do líder do governo para cada votação em que essa indicação ocorreu, excluídas as abstenções e faltas.

11. A disciplina em relação ao governador foi calculada com base na média de parlamentares de cada bancada estadual que seguiram a orientação do líder do partido a que pertencia o governador para cada votação em que essa orientação ocorreu, excluídas as abstenções e faltas.

12. Esta seção não pretende, portanto, explicar o comportamento dos parlamentares na Câmara dos Deputados. Cheibub, Figueiredo e Limongi (2006; 2009), e Desposato (2004) empregaram métodos estatísticos mais sofisticados para determinar os fatores que afetam esse comportamento.

13. Para mais detalhes sobre o processo de tramitação parlamentar dessas matérias, ver Arretche (2008).

14. Na verdade, tais perdas se estendem aos municípios em virtude de sua quota-parte na arrecadação do ICMS.

15. Os termos aspeados reproduzem as palavras do relator do PLP no 95/1996 (Lei Kandir) quando da discussão do projeto em votação de primeiro turno na Câmara dos Deputados em 27/8/1996.

16. Para mais detalhes sobre a tramitação dessas matérias, ver Arretche (2008).

17. Essa legislação envolve os regimes previdenciários de Estados e municípios, bem como sua participação nos regimes de previdência complementar; determina salários e subsídios dos cargos eleitos em todos os níveis de governo; estabelece os termos para a concessão de serviços públicos dos governos subnacionais, assim como as regras para contratações e licitações; define as regras para criação de municípios no âmbito de cada Estado; disciplina as normas gerais para demissão de funcionários públicos, além de disciplinar as regras segundo as quais os municípios devem exercer suas competências na política de desenvolvimento urbano. Em suma, em conjunto, esse tipo de legislação disciplina grande parte das condições de execução das políticas públicas sob competência de Estados e municípios.

18. O Estatuto da Cidade apenas regulamenta o art. 182 da CF 88 , que estabelece que as diretrizes gerais da política urbana a ser executada pelos municípios seriam definidas por lei federal, assim como o art. 21, que define como competência da União "instituir diretrizes para o desenvolvimento urbano". Do mesmo modo, a LDB é uma decorrência direta do art. 22, que estabelece como competência privativa da União instituir as "diretrizes e bases da educação nacional". Igualmente, a Lei de Concessões decorre de uma competência privativa da União (art. 22).

19. O Fundef (EC n⿳-14/1996) teve o potencial de "expropriar" até $15 \%$ das receitas de Estados e municípios (Castro, 2000). O Fundeb amplia essa "expropriação potencial" para $20 \%$, além de estabelecer um piso para os salários dos professores das redes estadual e municipal (aprovado no governo Lula I). A EC no 29/2000, por sua vez, vincula $12 \%$ das receitas dos Estados e 15\% das receitas dos municípios com gastos em saúde. A EC no 25 / 2000 reviu o art. 29 da CF 88, que previa que os municípios seriam autônomos para definir a remuneração de seus vereadores, estabelecendo que o total da despesa com o financiamento do poder legislativo municipal não poderia ultrapassar o percentual que varia de $3 \%$ a $8 \%$ do somatório da receita tributária e das transferências, de acordo com a quantidade de habitantes de cada município. A EC 
nํ31/2000, que criou o Fundo de Combate à Pobreza federal, obriga também os Estados e municípios a criarem seus respectivos fundos de combate à pobreza. Finalmente, a $\mathrm{EC} \mathrm{n} \mathrm{0} 30 / 2000$ alterou o art. 100 da CF 88 , fixando prazos para o pagamento dos precatórios judiciais e delimitando as condições em que estes poderiam ser convertidos em títulos da dívida pública.

20. Em duas situações, essa posição de Itamar Franco como governador assumiu dimensões dramáticas: em relação ao pagamento das dívidas do Estado de Minas Gerais e à colaboração do Estado no enfrentamento da crise de energia.

21. Essa tabela sintetiza informações mais detalhadas apresentadas na Tabela 1 do Anexo.

22. Há onze votações que foram unânimes e inválidas porque não atingiram o quórum necessário para aprovação do projeto em questão.

23. Para todos os gráficos apresentados, o desvio padrão é sistematicamente inferior às médias, o que indica que estas são medidas confiáveis. Estão apresentados no extremo direito dos gráficos os Estados para os quais não foi possível obter informação para a orientação de voto do partido do governador por este pertencer a um pequeno partido. Quando o governador pertence a um partido pequeno, não há indicação da orientação do partido. Nesses casos, o $\mathrm{N}$ de votações ao qual foi possível determinar a indicação de votação fica prejudicado.

24. Observe-se que essa definição considera que a ausência e a abstenção na votação de matérias de interesse federativo não sejam computadas como evidências de falta de coesão, o que tende a subestimar a fidelidade dos parlamentares aos prováveis interesses da bancada caso esta estivesse coesa no objetivo de vetar uma iniciativa legislativa que afetava negativamente os interesses dos governos territoriais.

25. Essa interpretação está baseada no exame dos debates nas sessões que precederam a votação da Lei de Concessões, da Lei de Licitações e da Lei Camata, sendo confirmada pelos resultados da votação.

26. Lutz comparou 32 países examinando a relação entre as estratégias para aprovação de emendas à Constituição e as taxas de emendamento, encontrando elevada correlação entre essas variáveis. A estratégia menos exigente seria aquela em que uma votação legislativa seria suficiente para emendar a Constituição. Nesses países, a taxa anual média de emendamento é de 5,6. Em sua classificação, uma exigência adicional, capaz de afetar negativamente as taxas de aprovação, consistiria em requerer uma eleição interveniente entre duas votações sobre a mesma proposta de emenda. Nesse caso, a taxa média anual de emendamento cai para 1,3.

27. Os Estados Unidos, por exemplo, adotaram o princípio de que as alterações devem ser referendadas por uma maioria de quatro quintos das assembleias estaduais. $\mathrm{Na}$ Suíça e na Austrália, mudanças legislativas que afetem os interesses das regiões devem ser aprovadas por um referendo, com aprovação da maioria dos eleitores e da maioria dos Estados. Ambas as estratégias criam arenas adicionais de veto, conferindo oportunidades de veto às minorias afetadas pelas decisões tomadas pela maioria nas arenas decisórias centrais. 


\section{Continuidades e Descontinuidades da Federação Brasileira...}

\section{REFERÊNCIAS BIBLIOGRÁFICAS}

ABRUCIO, Fernando L. e COSTA, Valeriano Mendes F. (1999), Reforma do Estado e o Contexto Federativo Brasileiro. São Paulo, Fundação Konrad-Adenauer-Stiftung.

ALMEIDA, Maria Hermínia Tavares de. (2001), “Federalismo, Democracia e Governo no Brasil: Idéias, Hipóteses e Evidências". BIB, vol. 51, pp. 13-34.

. (2005), "Recentralizando a Federação?". Revista de Sociologia e Política, vol. 24, pp. 29-40.

ARRETCHE, Marta. (2002), "Federalismo e Relações Intergovernamentais no Brasil: A Reforma de Programas Sociais". DADOS, vol. 45, no 3, pp. 431-458.

. (2004), "Toward a Unified and More Equitable System: Health Reform in Brazil", in R. Kaufmann e J. Nelson (eds.), Crucial Needs, Weak Incentives: Social Sector Reform, Democratization, and Globalization in Latin America. Washington/Baltimore/London, Woodrow Wilson Center/Johns Hopkins University Press.

. (2005), “Quem Taxa e Quem Gasta: A Barganha Federativa na Federação Brasileira". Revista de Sociologia e Política, vol. 24, pp. 69-85.

. (2008), “The Veto Power of Subnational Governments in Brazil”. Brazilian Political Science Review, vol. 2, pp. 40-73.

BUCHANAN, James M. (1995), "Federalism as an Ideal Political Order and an Objective for Constitutional Reform". Publius: The Journal of Federalism, vol. 25, no 2, pp. 19-27.

CASTLES, Francis G. e UHR, John. (2005), “Australia: Federal Constraints and Institutional Innovations", in H. Obinger, S. Leibfried e F. G. Castles (eds.), Federalism and the Welfare State. New World and European Experiences. Cambridge, Cambridge University Press.

CASTRO, Jorge Abrahão. (2000), Avaliação do Impacto do Fundef nas Receitas Fiscais de Estados e Municípios. Texto para discussão. Brasília, Secretaria do Tesouro Nacional.

CHEIBUB, José Antonio, FIGUEIREDO, Argelina e LIMONGI, Fernando. (2006), The Politics of Federalism in Brazil: The Role of Governors in the Brazilian Congress. Trabalho apresentado no workshop State Politics and Institutions in Comparative Perspective: Lessons from Brazil. Centre for Brazilian Studies, University of Oxford.

. (2009), "Political Parties and Governors as Determinants of Legislative Behavior in Brazil's Chamber of Deputies, 1988-2006". Latin American Politics and Society, vol. 51, no 1, pp. 1-30.

CHIBBER, Pradeep K. e KOLLMAN, Ken. (2004), The Formation of National Party Systems. Princeton, Princeton University Press.

COUTO, Cláudio Gonçalves e ARANTES, Rogério Bastos. (2006), “Constituição, Governo e Democracia no Brasil". Revista Brasileira de Ciências Sociais, vol. 21, no 61, pp. 41-62.

DESPOSATO, Scott. (2004), “The Impact of Federalism on National Party Cohesion in Brazil". Legislative Studies Quarterly, vol. 29, no 2, pp. 259-285. 
GIBSON, Edward L. (ed.). (2004), Federalism and Democracy in Latin America. Baltimore/ London, Johns Hopkins University Press.

IMMERGUT, Ellen M. (1996), “As Regras do Jogo: A Lógica da Política de Saúde na França, na Suíça e na Suécia". Revista Brasileira de Ciências Sociais, vol. 30, no 11, pp. 139-163.

INMAN, Robert P. e RUBINFELD, Daniel L. (1997), “The Political Economy of Federalism", in D. Mueller (ed.), Perspectives on Public Choice: A Handbook. Cambridge, Cambridge University Press.

KING, Gary, KEOHANE, Robert O. e VERBA, Sidney. (1994), Designing Social Inquiry. Scientific Inference in Qualitative Research. Princeton, Princeton University Press.

LEIBFRIED, Stephan, CASTLES Francis G. e OBINGER, Herbert. (2005), “'Old' and 'New Politics' in Federal Welfare States", in H. Obinger, S. Leibfried e F. G. Castles (eds.), Federalism and the Welfare State. New World and European Experiences. Cambridge, Cambridge University Press.

LEIBFRIED Stephan e PIERSON, Paul. (1995), "Semisovereign Welfare States; Social Policy in a Multitiered Europe", in S. Leibfried e P. Pierson (eds.), European Social Policy. Between Fragmentation and Integration. Washington, The Brookings Institution.

LIJPHART, Arend. (1999), Patterns of Democracy: Government Forms and Performance in Thirty-Six Countries. New Haven, Yale University Press.

LUTZ, Donald S. (1994), "Toward a Theory of Constitutional Amendment". American Political Science Review, vol. 88, no 2, pp. 355-370.

MANOW, Philip. (2005), "Germany: Co-Operative Federalism and the Overgrazing of the Fiscal Commons", in H. Obinger, S. Leibfried e F. G. Castles (eds.), Federalism and the Welfare State. New World and European Experiences. Cambridge, Cambridge University Press.

MELO, Marcus André. (2002), As Reformas Constitucionais no Brasil: Instituições Políticase Processo Decisório. Rio de Janeiro, Revan.

. (2005), “O Sucesso Inesperado das Reformas de Segunda Geração: Federalismo, Reformas Constitucionais e Política Social”. DADOS, vol. 48, no 4, pp. 845-889.

MOORE, Carolyn, JACOBY, Wade e GUNLICKS, Arthur B. (2008), “German Federalism in Transition". German Politics, vol. 17, no 4, pp. 393-407.

OBINGER, Herbert, CASTLES, Francis G. e LEIBFRIED, Stephan. (2005), “Introduction: Federalism and the Welfare State", in H. Obinger, S. Leibfried e F. G. Castles (eds.), Federalism and the Welfare State. New World and European Experiences. Cambridge, Cambridge University Press.

OBINGER, Herbert, LEIBFRIED, Stephan e CASTLES, Francis G. (eds.). (2005), Federalism and the Welfare State. New World and European Experiences. Cambridge, Cambridge University Press.

OBINGER, Herbert et alii. (2005), "Switzerland: The Marriage of Direct Democracy and Federalism", in H. Obinger, S. Leibfried e F. G. Castles (eds.), Federalism and the Welfare State. New World and European Experiences. Cambridge, Cambridge University Press. 


\section{Continuidades e Descontinuidades da Federação Brasileira...}

PIERSON, Paul. (1995), "Fragmented Welfare States: Federal Institutions and the Development of Social Policies". Governance: An International Journal of Policy and Administration, vol. 8, no 4, pp. 449-478.

. (2004), "Positive Feedback and Path Dependence", in P. Pierson, Politics in Time: History, Institutions, and Social Analysis. Princeton, Princeton University Press.

. (2007), "The Rise and Reconfiguration of Activist Government", in P. Pierson e T. Skocpol (eds.), The Transformation of American Politics. Activist Government and the Rise of Conservatism. Princeton, Princeton University Press.

RODDEN, Jonathan A. (2006), Hamilton's Paradox. The Promise and Peril of Fiscal Federalism. Cambridge, Cambridge University Press.

SAMUELS, David J. e MAINWARING, Scott. (2004), "Strong Federalism, Constraints on the Central Government, and Economic Reform in Brazil", in E. L. Gibson (ed.), Federalism and Democracy in Latin America. Baltimore/London, Johns Hopkins University Press.

SCHARPF, Fritz. (1988), "The Joint-Decision Trap: Lessons from German Federalism and European Integration". Public Administration, vol. 66, pp. 239-278.

SELLERS, Jefferey M. e LIDSTRÖM, Anders. (2007), “Decentralization, Local Government, and the Welfare State". Governance, vol. 20, no 4, pp. 609-632.

STEGARESCU, Dan. (2005), "Public Sector Decentralisation: Measurement Concepts and Recent International Trends". Fiscal Studies, vol. 26, no 3, pp. 301-338.

SKOCPOL, Theda. (1992), Protecting Soldiers and Mothers: The Political Origins of Social Policy in United States. Harvard, Belknap Press.

SOUZA, Celina. (2002), "Brazil: The Prospects of a Center-Constraining Federation in a Fragmented Polity". Publius. The Journal of Federalism, vol. 32, no 2, pp. 23-48.

(2008), “Federalismo: Teorias e Conceitos Revisitados". BIB, no 65, pp. 27-48.

STEPAN, Alfred. (1999), "Para uma Nova Análise Comparativa do Federalismo e da Democracia: Federações que Restringem ou Ampliam o Poder da Demos". DADOS, vol. 42, no 2, pp. 197-251.

TREISMAN, Daniel. (2007), The Architecture of Government: Rethinking Political Decentralization. Cambridge, Cambridge University Press.

TSEBELIS, George. (1997), "Processo Decisório em Sistemas Políticos: Veto Players no Presidencialismo, Parlamentarismo, Multicameralismo e Multipartidarismo". Revista Brasileira de Ciências Sociais, vol. 12, no 34, pp. 89-118.

WEAVER, R. Kent e ROCKMAN, Bert A. (eds.). (1993), Do Institutions Matter? Government Capabilities in the United States and Abroad. Washington, Brookings.

WEINGAST, Barry. (1995), “The Economic Role of Political Institutions: Market-Preserving Federalism and Economic Development. The Journal of Law, Economics, \& Organization, vol. 11, no 1, pp. 1-31. 


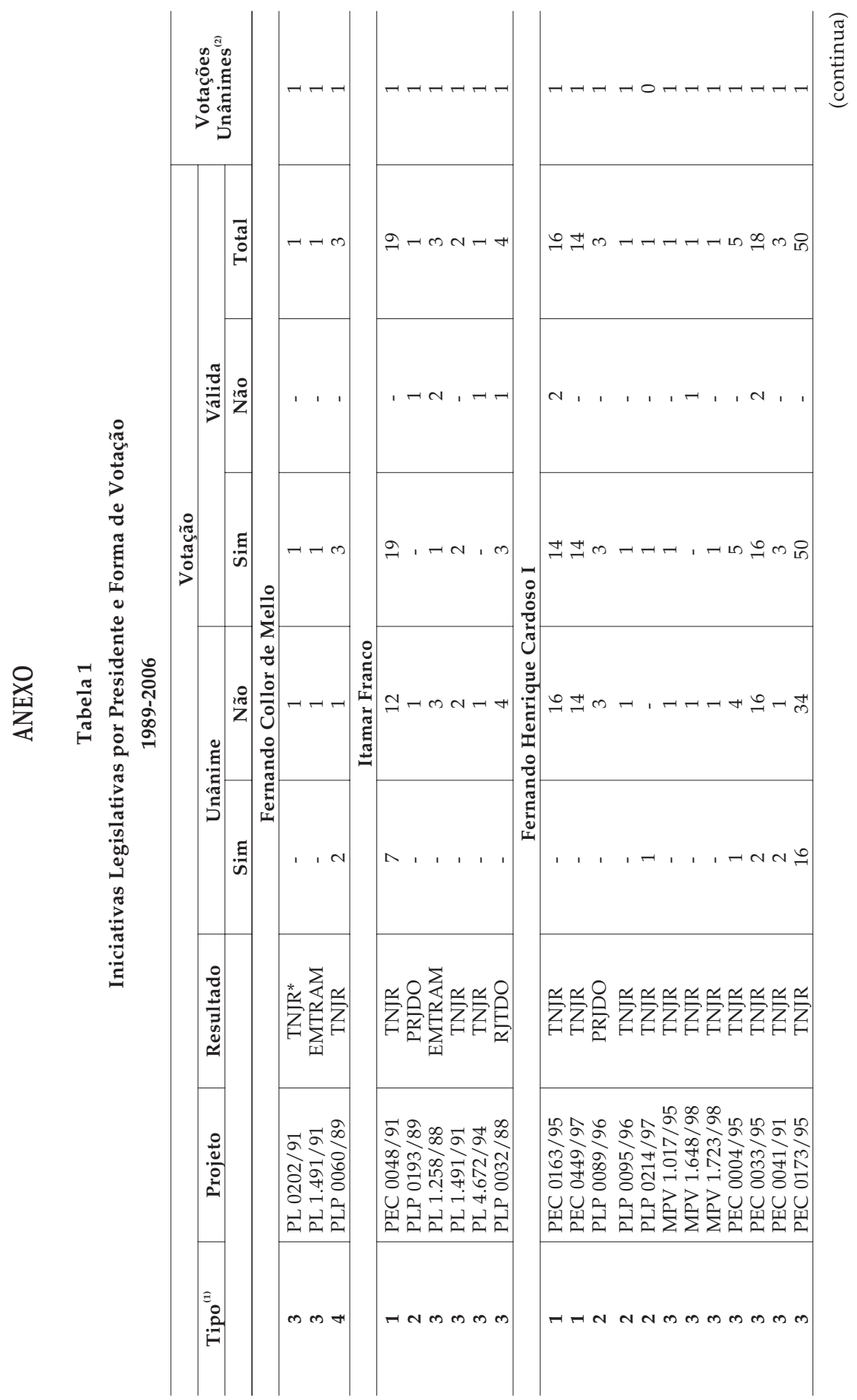


Continuidades e Descontinuidades da Federação Brasileira...

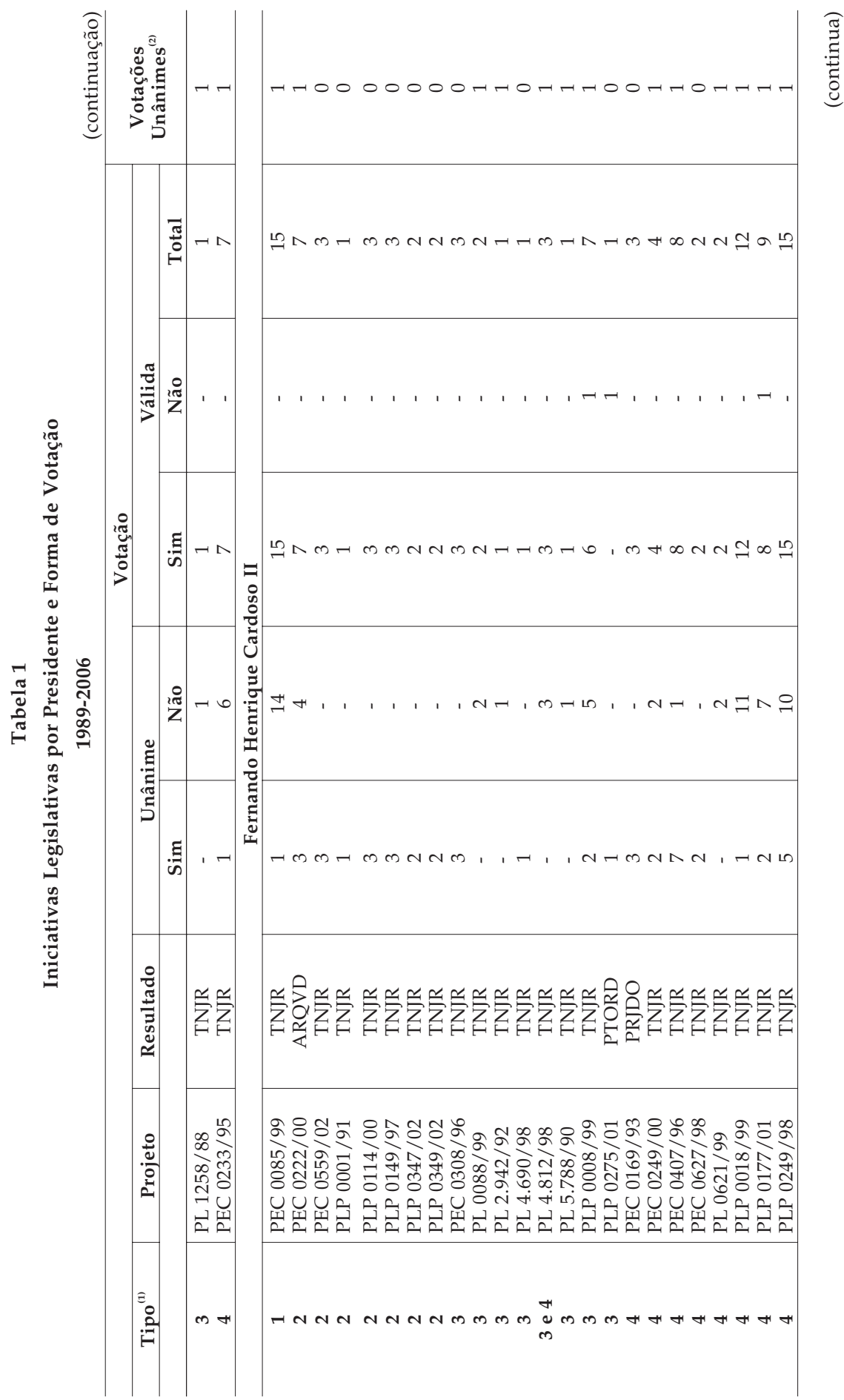




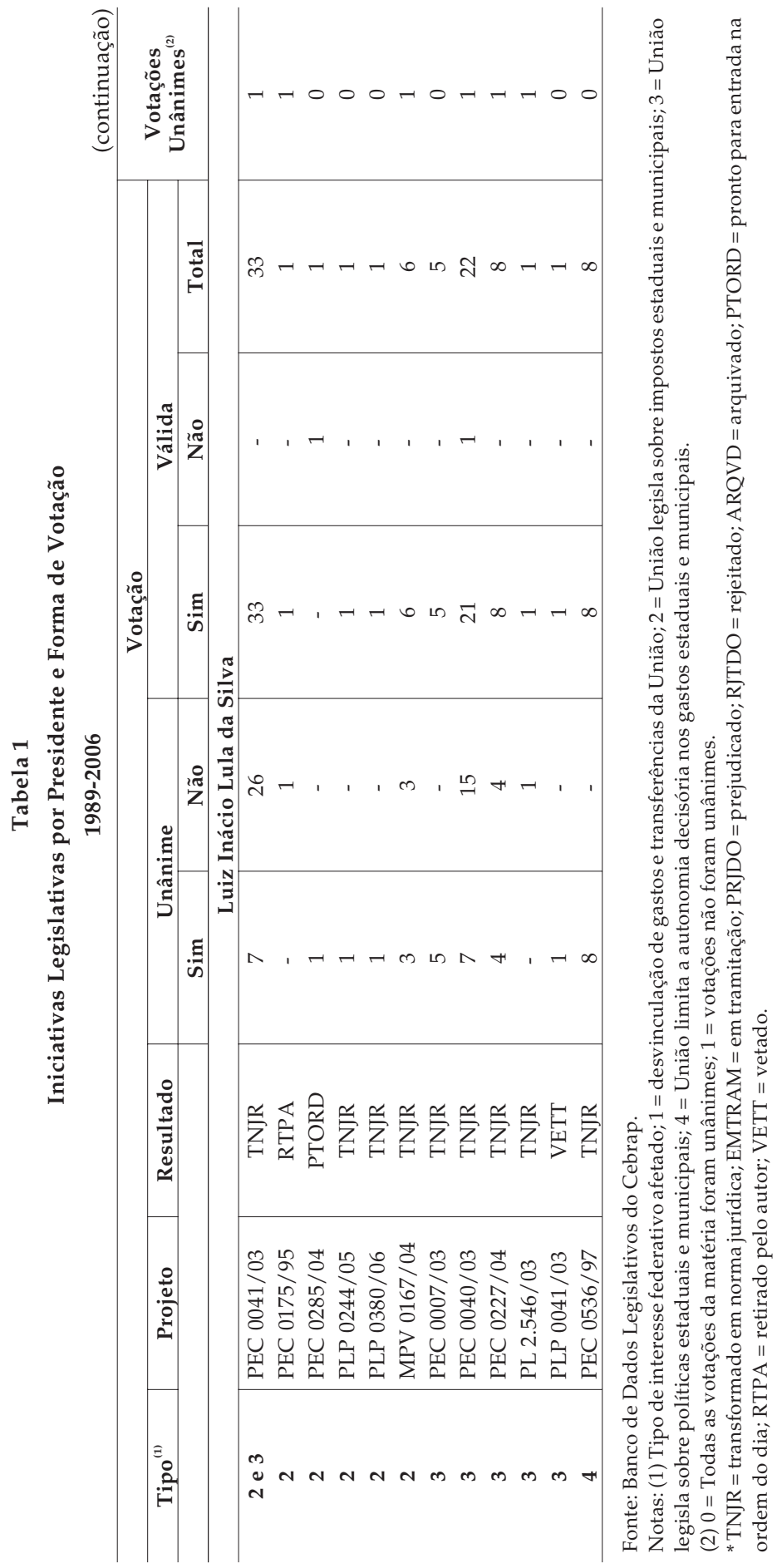




\section{ABSTRACT \\ Continuities and Discontinuities in the Brazilian Federation: How 1988 Made 1995 Possible}

The article shows that the drafters of the 1988 Brazilian Constitution approved political institutions that combine broad jurisdictional authority to the Federal government along with limited institutional veto powers to subnational governments. The study has examined 59 initiatives of legislation addressing federal matters voted by the Chamber of Deputies from 1989 to 2006. The article explores how political institutions affect the decision-making process of federal issues, by distinguishing main actors' preferences from federal institutions, controlled by presidential terms.

Key words: federalism; decision-making process; 1988 Constitution

\section{RÉSUMÉ}

Continuités et Discontinuités de la Fédération Brésilienne: Comment 1988 a Rendu 1995 plus Facile

Dans cet article, on cherche à montrer que les responsables de la Constitution brésilienne de 1988 ont créé un modèle d'État federal qui associe une large autorité juridictionnelle à l'État central avec des possibilités institutionnelles assez limitées de veto aux gouvernements subnationaux. L'etude tien pour base l'examen des 59 initiatives en matière d'intérêt federal soumises au Congrès national de 1989 à 2006. On y examine les déterminants fédératifs du processus décisionnel, tout en faisant la distinction entre les préférences explicites des principaux acteurs et l'effet des institutions fédératives, contrôlées par mandat présidentiaux.

Mots-clé: fédéralisme; processus décisionnel; Constitution de 1988 